\title{
Disentangling the rates of carbonyl sulfide (COS) production and consumption and their dependency on soil properties across biomes and land use types
}

\author{
Aurore Kaisermann, Jérôme Ogée, Joana Sauze, Steven Wohl, Sam P. Jones, Ana Gutierrez, and Lisa Wingate \\ INRA/Bordeaux Science Agro, UMR 1391 ISPA, Villenave d'Ornon, 33140, France
}

Correspondence: Aurore Kaisermann (aurore.kaisermann@inra.fr)

Received: 28 December 2017 - Discussion started: 8 January 2018

Revised: 21 May 2018 - Accepted: 6 June 2018 - Published: 5 July 2018

\begin{abstract}
Soils both emit and consume the trace gas carbonyl sulfide (COS) leading to a soil-air COS exchange rate that is the net result of two opposing fluxes. Partitioning these two gross fluxes and understanding their drivers are necessary to estimate the contribution of soils to the current and future atmospheric COS budget.

Previous efforts to disentangle the gross COS fluxes from soils have used flux measurements on air-dried soils as a proxy for the COS emission rates of moist soils. However, this method implicitly assumes that COS uptake becomes negligible and that COS emission remains steady while soils are drying. We tested this assumption by simultaneously estimating the soil COS sources and sinks and their temperature sensitivity $\left(Q_{10}\right)$; these estimates were based on soil-air COS flux measurements on fresh soils at different COS concentrations and two soil temperatures. Measurements were performed on 27 European soils from different biomes and land use types in order to obtain a large range of physicalchemical properties and identify the drivers of COS consumption and production rates.

We found that COS production rates from moist and airdried soils were not significantly different for a given soil and that the COS production rates had $Q_{10}$ values $(3.96 \pm 3.94)$ that were larger and more variable than the $Q_{10}$ for COS consumption $(1.17 \pm 0.27)$. COS production generally contributed less to the net flux at lower temperatures but this contribution of COS production increased rapidly at higher temperatures, lower soil moisture contents and lower COS concentrations. Consequently, measurements at higher COS concentrations (viz. $1000 \mathrm{ppt}$ ) always increased the robustness of COS consumption estimates. Across the range of biomes and land use types COS production rates co-varied
\end{abstract}

with total soil nitrogen concentrations $(r=0.52, P<0.05)$ and mean annual precipitation $(r=0.53, P<0.05)$, whilst the gross COS uptake rate and the first-order COS hydrolysis rate constant co-varied significantly with the microbial biomass nitrogen $(\mathrm{N})$ content of the soils $(r=-0.74$ and $0.64, P<0.05$ and $P<0.05$, respectively). Collectively our findings suggest a strong interaction between soil nitrogen and water cycling on COS production and uptake, providing new insights into how to upscale the contribution of soils to the global atmospheric COS budget.

\section{Introduction}

Carbonyl sulfide (COS) is a powerful greenhouse gas and its atmospheric concentration has varied considerably throughout the Earth's history (Ueno et al., 2009). In the present-day stratosphere, COS photolysis contributes to the formation of aerosol particles that also cool the planet, consequently offsetting the global warming potential of COS (Brühl et al., 2012). Currently, the concentration of COS in the troposphere is around $500 \mathrm{ppt}$ (or pmol mol${ }^{-1}$ ) almost 1 million times less than the current atmospheric $\mathrm{CO}_{2}$ concentration. However, the relative seasonal amplitude of COS is about 5 times larger than that of $\mathrm{CO}_{2}$ and has led to $\mathrm{COS}$ being proposed as a powerful tracer of gross primary production (GPP) over land (e.g. Montzka et al., 2007; Sandoval-Soto et al., 2005; Whelan et al., 2017). This is because the removal of $\mathrm{COS}$ from the atmosphere during summer months in the Northern Hemisphere is driven by the activity of plants over land that remove $\operatorname{COS}$ through an enzymatic reaction with 
carbonic anhydrase (CA) (Sandoval-Soto et al., 2005; Stimler et al., 2012), a ubiquitous enzyme particularly abundant in leaf mesophyll cells (Fabre et al., 2007).

Soils are also teeming with a diverse range of organisms such as bacteria, fungi and algae that also contain CAs (Elleuche and Pöggeler, 2010; Moroney et al., 2001; Smith and Ferry, 2000); thus, these organisms have the potential to remove $\mathrm{COS}$ from the atmosphere. For this reason, oxic soils are generally considered net sinks for atmospheric COS (Van Diest and Kesselmeier, 2008; Kesselmeier et al., 1999; Li et al., 2005; Whelan et al., 2017) albeit with a much weaker sink strength than vegetation (Berry et al., 2013; Campbell et al., 2017; Kettle et al., 2002; Launois et al., 2015). Some soils have also been found to be strong producers of COS, notably anoxic soils (Fried et al., 1993; Hines and Morrison, 1992; Whelan et al., 2013) in addition to some oxic soils with and without plant litter (Bunk et al., 2017; Kitz et al., 2017; Maseyk et al., 2014; Melillo et al., 1993; Sun et al., 2016; Whelan et al., 2016; Whelan and Rhew, 2015).

Despite the importance of soil COS fluxes for improving the global COS mass budget, the mechanisms underlying COS production and consumption by soils remain unclear. This is partly because it is difficult to disentangle the functional response of these two opposing fluxes in isolation and characterise how changes in the environment or soil properties impact the net COS flux. Recently physical and enzymatic models describing the consumption of COS by soils have been advanced (Ogée et al., 2016; Sun et al., 2015). However, equivalent mechanistic understanding of COS production is still lacking.

One approach for estimating COS emission rates from soils is to measure the net COS flux rate of air-dried soil samples (Whelan and Rhew, 2016; Whelan et al., 2016b). This assumes that the COS consumption by dry soils is negligible as hydrolysis by CA requires the presence of water to proceed (Van Diest and Kesselmeier, 2008; Ogée et al., 2016; Sun et al., 2015; Whelan and Rhew, 2016). Thus, with a further assumption that COS emission rates do not vary while soils are drying, COS emission rates can be retrieved from the net COS flux measured on fresh soils (Whelan et al., 2016). However, it is still not clear whether the COS production by soils is related to biological activity and, therefore, potentially varies with soil moisture. If this was the case, the described method for estimating COS production rates on dry soils could create strong biases in the partitioning of the net COS flux under wet or moist field conditions.

An alternative approach, presented by Conrad (1994), facilitates the simultaneous estimation of COS production and consumption on fresh soils, thereby providing a test of whether COS production changes with soil water content or not. Because this alternative approach requires the measurement of net COS fluxes at different atmospheric COS concentrations, it cannot be easily implemented in the field without large artefacts (Castro and Galloway, 1991; de Mello and Hines, 1994); however, it is well adapted to measurements on soil microcosms (Lehmann and Conrad, 1996; Conrad and Meuser, 2000; Whelan et al., 2016). So far very few studies have implemented this approach; thus the partitioning of COS fluxes at ambient concentrations still remains poorly explored (Whelan et al., 2017).

In this study, we used the approach from Conrad (1994) to estimate COS production and consumption rates simultaneously from moist soils near ambient COS concentrations. We combined this approach with a recently developed theoretical framework (Ogée et al., 2016) to retrieve COS production and first-order consumption rates on a range of soils from different biomes and land use types located in Europe and Israel. We then evaluated the effects of varying COS concentration, soil moisture and temperature on the COS production and consumption rates and assessed the potential role of soil properties such as $\mathrm{pH}$, texture, soil carbon and nitrogen, microbial biomass, etc., as drivers of COS gross fluxes.

\section{Materials and methods}

\subsection{Theory}

Assuming that the soil-air COS exchange rate in soil microcosms is governed by only three processes, namely diffusion through the soil column, production and uptake via hydrolysis, Ogée et al. (2016) proposed a steady-state, analytical model of the COS efflux at the soil surface $(F$, pmol $\mathrm{m}^{-2} \mathrm{~s}^{-1}$ ) as follows:

$F=\left(-\sqrt{k B \theta D} C_{a}+\rho_{\mathrm{b}} P \sqrt{\frac{D}{k B \theta}}\right) \tanh \left(z_{\max } \sqrt{\frac{k B \theta}{D}}\right)$,

where $D\left(\mathrm{~m}^{2} \mathrm{~s}^{-1}\right)$ is the COS diffusivity through the soil matrix, $k\left(\mathrm{~s}^{-1}\right)$ is the first-order COS hydrolysis rate constant and $P\left(\mathrm{pmol} \mathrm{kg}^{-1} \mathrm{~s}^{-1}\right)$ is the COS production rate. Other symbols are $B\left(\mathrm{~m}^{3} \mathrm{~m}^{-3}\right)$, the COS solubility in soil water, $\theta$ $\left(\mathrm{m}^{3} \mathrm{~m}^{-3}\right)$, the soil volumetric water content, $C_{a}\left(\mathrm{~mol} \mathrm{~m}^{-3}\right)$, the molar concentration of COS in air at the soil surface, $\rho_{\mathrm{b}}$ $\left(\mathrm{kg} \mathrm{m}^{-3}\right)$, the soil bulk density and $z_{\max }(\mathrm{m})$, the maximum soil depth. This equation assumes a finite soil depth $\left(z_{\max }\right)$ and uniform soil properties $\left(\theta, \rho_{\mathrm{b}} \ldots\right)$ and is, therefore, only suited for soil microcosm studies (Ogée et al., 2016).

Noting that $\tanh (a x) / x=a$ if $x \rightarrow 0$, when soil moisture tends to zero $(\theta \rightarrow 0)$, Eq. 1 simplifies to $F_{\text {dry }}=\rho_{\mathrm{b}} P_{\text {dry }} z_{\max }$, where $F_{\text {dry }}$ and $P_{\text {dry }}$ represent the net $\operatorname{COS}$ flux $(F)$ and the COS production rate $(P)$ of an air-dry soil, respectively. Thus, assuming that $P$ does not vary with soil moisture $(P=$ $\left.P_{\text {dry }}\right)$, the COS production rate can be estimated from measurements of the soil-to-air COS flux performed on air-dry soil samples. This method, hereafter referred to as "Method 1", has been recently proposed for partitioning soil COS sources and sinks (Whelan et al., 2016). By knowing the value of $P$ the COS hydrolysis rate constant $k$ can then be estimated from measurements of the soil-to-air COS flux performed on moist soils using Eq. (1). In practice a numerical 
iterative method must be implemented to find the value of $k$ that minimises the discrepancy between the observed and modelled fluxes (Ogée et al., 2016; Sauze et al., 2017).

Note that if the steady-state net soil COS flux $(F)$ is measured at different COS concentrations $\left(C_{a}\right)$, and provided that $P$ is known, it is possible to derive a different $k$ value for each $\left(F, C_{a}\right)$ pair of measurements. In theory each pair of measurements should provide the same hydrolysis rate constant, unless COS hydrolysis does not follow first-order kinetics and $k$ is not a true rate constant and varies with $C_{a}$. In fact this might well be the case as $k$ was originally hypothesised to be a catalysed rate constant (Kesselmeier et al., 1999; Lehmann and Conrad, 1996) that follows MichaelisMenten kinetics (Ogée et al., 2016; Protoschill-Krebs and Kesselmeier, 1992). In this case the hydrolysis rate would saturate to a maximal rate $V_{\max }$ at very high COS concentrations and would respond linearly to $C_{a}$ with a slope $k=$ $V_{\max } / K_{m}$ only at low concentrations (i.e. when $C_{a} \ll K_{m}$, where $K_{m}\left(\mathrm{~mol} \mathrm{~m}^{-3}\right)$ is the so-called Michaelis-Menten coefficient and corresponds to the COS concentration at which $k$ equals $\left.0.5 V_{\max } / k_{m}\right)$.

Carbonic anhydrases (CA) are a family of enzymes ubiquitous in soil micro-organisms (Wingate et al., 2009) that are known to catalyse COS hydrolysis (Protoschill-Krebs et al., 1992, 1996). Studies reporting their kinetic parameters are very scarce but tend to show relatively high values of $K_{m}$, around $40-60 \mu \mathrm{M}$ at $20^{\circ} \mathrm{C}$ (Protoschill-Krebs et al., 1992; Haritos et al., 2005; Ogawa et al., 2013; Ogée et al., 2016), i.e. more than 2 million times the atmospheric COS concentration (500 ppt or $20 \mathrm{pM}$ ). With such high $K_{m}$ values, and assuming that COS consumption by soils is only caused by carbonic anhydrase driven hydrolysis, the rate constant $k$ should be well approximated by $V_{\max } / k_{m}$; thus, $F$ should respond linearly to $C_{a}$ (see Eq. 1), without any sign of saturation. A near-linear response of $F$ to $C_{a}$ has indeed been demonstrated on all soils tested so far, even at COS concentrations 100 times higher than ambient levels (Lehmann and Conrad, 1996). Based on this observation, Eq. (1) can be re-written as follows:

$F=F_{0}-V_{\mathrm{d} 0} C_{a}$,

where $F_{0}$ is the gross flux of COS production, i.e. the flux $F$ when $C_{a}=0$, and $V_{\mathrm{d} 0}\left(\mathrm{~m} \mathrm{~s}^{-1}\right)$ is the COS deposition velocity onto the soil surface that would occur in the absence of COS production (i.e. if $P=0$ ). The gross flux of COS uptake is calculated by subtracting $F_{0}$ from the net COS flux $F$.

From Eq. (2) we can see that, by performing steady-state COS flux measurements at different COS concentrations, it is possible to simultaneously estimate $V_{\mathrm{d} 0}$ and $F_{0}$ from the slope and the intercept of a linear regression between the two variables, leading to the determination of $P$ and $k$ :

$$
\begin{aligned}
F_{0} & =\rho_{\mathrm{b}} P \sqrt{\frac{D}{k B \theta}} \tanh \left(z_{\max } \sqrt{\frac{k B \theta}{D}}\right), \\
V_{\mathrm{d} 0} & =\sqrt{k B \theta D} \tanh \left(z_{\max } \sqrt{\frac{k B \theta}{D}}\right) .
\end{aligned}
$$

In practice, this method, hereafter referred to as "Method 2", is performed in three steps. First a 3-point linear regression is performed between $F$ and $C_{a}$ data to estimate $F_{0}$ and $V_{\mathrm{d} 0}$ for each microcosm using the $1 \mathrm{~m}$ function in $\mathrm{R}$. Then the value of $k$ that satisfies Eq. (3b) is obtained using an iterative numerical method (fzero function in the Pracma Package; Borchers, 2017). Finally this $k$ value is introduced into Eq. (3a) to estimate $P$ from $F_{0}$. Values for $B$ are estimated from soil temperature using Wilhelm et al. (1977) and the COS effective diffusivity $D$ is estimated using the empirical formulation of Moldrup et al. (2003) for repacked soils (see also Ogée et al., 2016).

\subsection{Soil sampling and preparation}

Soils from 27 locations were collected along a latitudinal gradient in Europe and Israel during the summer of 2016. These locations were selected to cover a range of biomes and land use as well as soil physico-chemical properties (see Tables 1 and S1 in the Supplement). The first $10 \mathrm{~cm}$ of soil was collected at three locations at each site, sealed in plastic bags and sent to INRA Bordeaux after collection with no special requirements imposed for the transportation of the soil samples. Upon reception, the different soils were sieved using a $4 \mathrm{~mm}$ mesh, homogenised and stored at $4{ }^{\circ} \mathrm{C}$. The sieving was performed to ensure a representative sample of only soil and to avoid introducing any additional and (uncontrolled) plant litter effects, which could potentially cause variability between sample replicates and complicate the interpretation of the net and gross COS fluxes. We justify this experimental choice as our overall goal was to derive and validate a model of soil COS fluxes regulated by commonly quantified soil physical, chemical and biological characteristics. Our main hypothesis is that the drivers identified in our study would still be applicable in undisturbed soils. Sieved soils were then separated into two batches. One batch was air-dried by spreading soil in a tray and regularly mixing it every 2-3 days for 1-2 weeks before measuring it to estimate the air-dried COS production rate $\left(P_{\mathrm{dry}}\right)$; this batch is hereafter referred to as "dry". The other batch was stored at $4{ }^{\circ} \mathrm{C}$ for several weeks until it was measured to estimate the COS production and consumption rates of fresh soils ( $P$ and $k)$; this batch is hereafter referred to as "moist".

For both methods, measurements were performed in triplicates, using soil microcosms consisting of custom-made glass jars $\left(0.825 \mathrm{dm}^{3}\right.$ volume, $8.85 \mathrm{~cm}$ internal diameter $)$. During a 2-week incubation period in a climate-controlled chamber, the microcosms remained open to the air circu- 
Table 1. Locations, names, climatic descriptions and land use characteristics of sites sampled across Europe and Israel. The two names in bold represent the two fertilised parcels in manipulation field experiments. Ubeda_Veg and Ubeda_noVeg represent soils sampled in the same location but with or without vegetation, respectively. Altitude, mean annual temperature (MAT) and precipitation (MAP) are estimated from the literature.

\begin{tabular}{|c|c|c|c|c|c|c|c|c|c|}
\hline Site ID & Country & Site & Biome & Land use & $\begin{array}{r}\text { Latitude } \\
\left({ }^{\circ} \mathrm{N}\right)\end{array}$ & $\begin{array}{r}\text { Longitude } \\
\left({ }^{\circ} \mathrm{E}\right)\end{array}$ & $\begin{array}{r}\text { Altitude } \\
(\mathrm{m})\end{array}$ & $\begin{array}{r}\text { MAT } \\
\left({ }^{\circ} \mathrm{C}\right)\end{array}$ & $\begin{array}{l}\text { MAP } \\
(\mathrm{mm})\end{array}$ \\
\hline FI-Hyy & Finland (FI) & Hyytiala & Boreal & Forest & 61.8 & 24.3 & 187 & 3.8 & 709 \\
\hline FI-Var1 & Finland (FI) & Varrio1 & Boreal & Forest & 67.8 & 29.6 & 400 & -1 & 660 \\
\hline FI-Var2 & Finland (FI) & Varrio2 & Boreal & Forest & 67.8 & 29.6 & 400 & -1 & 660 \\
\hline SE-Hyl & Sweden (SE) & Hyltemossa & Boreal & Forest & 56.1 & 13.4 & 111 & 7 & 830 \\
\hline SE-Nor & Sweden (SE) & Norunda & Boreal & Forest & 60.1 & 17.5 & 71 & 5.6 & 544 \\
\hline SE-Ros2 & Sweden (SE) & Rosinedal_Cont & Boreal & Forest & 64.2 & 19.7 & 145 & 1.8 & 614 \\
\hline SE-Ros1 & Sweden (SE) & Rosinedal_Fert & Boreal & Forest & 64.2 & 19.7 & 145 & 1.8 & 614 \\
\hline SE-Sva & Sweden (SE) & Svartberget & Boreal & Forest & 64.2 & 19.8 & 161 & 1.8 & 614 \\
\hline ES-Amo & Spain (ES) & Amoladeras & Mediterranean & Grassland & 36.8 & -2.3 & 54 & 18.5 & 200 \\
\hline ES-Bal & Spain (ES) & Balsablanca & Mediterranean & Grassland & 36.9 & -2.0 & 200 & 18.5 & 220 \\
\hline ES-Ube1 & Spain (ES) & Ubeda_Veg & Mediterranean & Agrosystem & 37.9 & -3.2 & 366 & 14.8 & 20.4 \\
\hline ES-Ube2 & Spain (ES) & Ubeda_noVeg & Mediterranean & Agrosystem & 37.9 & -3.2 & 366 & 14.8 & 20.4 \\
\hline IL-Reh & Israel (IL) & Rehovot & Mediterranean & Agrosystem & 31.9 & 34.8 & 50 & 19.7 & 185 \\
\hline IL-Yat & Israel (IL) & Yatir & Mediterranean & Forest & 31.3 & 35.1 & 661 & 17.9 & 292 \\
\hline PT-Cor & Portugal (PT) & Coruche & Mediterranean & Forest & 39.1 & -8.3 & 156 & 17 & 656 \\
\hline PT-Mit & Portugal (PT) & Mitra & Mediterranean & Forest & 38.5 & -8.0 & 240 & 15.6 & 656 \\
\hline $\mathrm{CH}-\mathrm{Cha}$ & Switzerland $(\mathrm{CH})$ & Chamau & Temperate & Grassland & 47.2 & 8.4 & 393 & 9.5 & 1136 \\
\hline $\mathrm{CH}-\mathrm{Dav}$ & Switzerland $(\mathrm{CH})$ & Davos & Temperate & Forest & 46.8 & 9.9 & 1639 & 2.8 & 1062 \\
\hline $\mathrm{CH}-\mathrm{Fru}$ & Switzerland $(\mathrm{CH})$ & Fruebuel & Temperate & Grassland & 47.1 & 8.5 & 982 & 7.2 & 1651 \\
\hline CH-Lae & Switzerland $(\mathrm{CH})$ & Laegern & Temperate & Forest & 47.1 & 8.5 & 866 & 8.3 & 1100 \\
\hline $\mathrm{CH}-\mathrm{Oe} 2$ & Switzerland $(\mathrm{CH})$ & Oensingen & Temperate & Agrosystem & 47.3 & 7.7 & 452 & 9.2 & 1100 \\
\hline DE-Hai & Germany (DE) & Hainich & Temperate & Forest & 51.1 & 10.5 & 463 & 7.9 & 646 \\
\hline DE-Lei & Germany (DE) & Leinefelde & Temperate & Forest & 51.3 & 10.4 & 474 & 7.6 & 775 \\
\hline DK-Sor & Denmark (DK) & Soro & Temperate & Forest & 55.5 & 11.6 & 45 & 8.5 & 564 \\
\hline FR-Hes & France (FR) & Hesse & Temperate & Forest & 48.7 & 7.1 & 313 & 9.7 & 650 \\
\hline FR-Lqu1 & France (FR) & Laqueuille_Fert & Temperate & Grassland & 45.6 & 2.7 & 1041 & 7.9 & 897 \\
\hline FR-Lqu2 & France (FR) & Laqueuille_Cont & Temperate & Grassland & 45.6 & 2.7 & 1041 & 7.9 & 897 \\
\hline
\end{tabular}

lating in the climate chamber (MD1400, Snijders, Tillburg, $\mathrm{NL})$ that had $\mathrm{CO}_{2}$ and $\mathrm{COS}$ concentrations controlled at around $400 \mathrm{ppm}$ and $500 \mathrm{ppt}$, respectively, i.e. close to ambient levels. The same $\mathrm{CO}_{2}$ concentration was also used to purge the air inlet during the gas exchange measurements, so that the microcosms were never exposed to $\mathrm{CO}_{2}$ levels much higher than those of ambient air or those used during the gasexchange measurements (see below).

For Method 1, 350-400 g of air-dried soil was placed in each microcosm and acclimated for 2-3 days in the dark prior to gas exchange measurements. For Method 2, 200$300 \mathrm{~g}$ of equivalent dry soil was used and maintained at $30 \%$ of maximum water holding capacity (WHC) for 2 weeks in the dark until gas exchange measurements were performed. Prior to this incubation period, the WHC of each soil was estimated using the method of Haney and Haney (2010). When fresh soils were too wet ( $>30 \%$ WHC), they were airdried until they reached 10-20\% WHC, then re-humidified to $30 \% \mathrm{WHC}$ at the start of the 2-week incubation period. Care was taken to avoid measuring the so-called "Birch effect" (Jarvis et al., 2007) during gas exchange measurements. Because the largest water addition was performed just before the incubation period (especially on soils that were shipped from very dry places) all gas exchange measurements were delayed for 2 weeks to ensure fluxes had stabilised during the incubation period and that they were outside the decay curve of the Birch effect. Throughout these 2 weeks, microcosms were kept unsealed in the dark and the moisture contents were monitored gravimetrically every 2 days whereupon, extra but small, water additions were made (about $2-5 \mathrm{~g}$ of distilled water for an average water content of $58.7 \pm 16 \mathrm{~g}$ ); water additions were made no later than $24 \mathrm{~h}$ before the start of the gas exchange measurements.

\subsection{Gas exchange measurements}

Glass soil microcosms were equipped with customised screw-tight glass lids cut to the exact size of the microcosm area and finely ground to provide a glass-on-glass seal that was held in place by screwing the threaded metal lid onto the jar over the glass panel. The lids were equipped with two stainless steel Swagelok ${ }^{\circledR}$ (Swagelok, Solon, OH, USA) fittings to connect to the $3.175 \mathrm{~mm}\left(1 / 8^{\prime \prime}\right)$ Teflon inlet and outlet lines of the measurement system. Sealing was ensured 
using PTFE washers that were previously tested and shown not to emit COS. A stainless steel temperature probe (3wire PT100, $15 \mathrm{~cm}$ length, $3 \mathrm{~mm}$ diameter, reference RS 362 $9935)$ continuously recorded the average soil temperature in each microcosm. Dry synthetic air was then adjusted to the desired $\mathrm{CO}_{2}(399 \pm 6 \mathrm{ppm})$ and $\mathrm{COS}$ mixing ratios and supplied to the microcosms using the same system as described in Gimeno et al. (2017). All pots were weighed before and after gas exchange measurements to calculate water loss. On average, the water loss was $0.2 \pm 0.005 \mathrm{~g}$ per hour or $4 \pm 1 \%$ of the initial water amount (i.e. a reduction of the volumetric water content of less than $0.01 \mathrm{~cm}^{3} \mathrm{~cm}^{-3}$ ). Additional gas exchange measurements were also performed after the end of the sequence and we could verify that the $\mathrm{COS}$ and $\mathrm{CO}_{2}$ fluxes of a given microcosm (at a given temperature and COS concentration) were not significantly different between the first and second sequences ( $16 \mathrm{~h}$ apart; see below). This was a clear indication that the small water loss during the duration of the gas exchange measurements did not significantly impact the $\mathrm{COS}$ and $\mathrm{CO}_{2}$ fluxes. The inlet and outlet airstreams of each microcosm were sequentially analysed using a midinfrared quantum cascade laser spectrometer (QCLS, Aerodyne Research Inc Billerica, MA, USA), coupled upstream to a Nafion dryer (MD-070-24-S-2, Perma Pure LLC, Lakewood, NJ, USA) to remove matrix effects caused by water vapour (Kooijmans et al., 2016). To account for instrument drift, an auto-background was regularly implemented (typically every $38 \mathrm{~min}$ ) for $120 \mathrm{~s}$ using a dry $\mathrm{N}_{2}$ bottle. A 2-point calibration scheme was also implemented using the same dry $\mathrm{N}_{2}$ bottle (measured every $14 \mathrm{~min}$ ) and an Aculifetreated cylinder (Air Liquide USA, Houston, TX, USA) filled with compressed air and $524.8 \mathrm{pmol}(\mathrm{COS}) \mathrm{mol}^{-1}$ calibrated to the NOAA-Scripps Institution of Oceanography provisional scale. This second cylinder was measured every 14 to 56 min depending on the sequence used.

Using a custom-made multiplexed system (Sauze et al., 2017), six jars with six different soils and one empty jar (blank) were sequentially measured over ca. $18 \mathrm{~h}$ to simultaneously investigate six different soils under identical conditions (Fig. S2). Over this period the measuring sequence consisted of eight steps that measured the COS fluxes from all the microcosms at two different temperatures $\left(18\right.$ and $23^{\circ} \mathrm{C}$ ) and three different COS concentration levels (around 100, 500 and $1000 \mathrm{ppt}$ ), with an acclimation time of ca. $2 \mathrm{~h}$ following a change in temperature and $40 \mathrm{~min}$ following a change in COS concentration (see Fig. S2). While only 14 min were usually required to stabilise the $\operatorname{COS}$ mixing ratio on the chamber lines after a step change in the COS mixing ratio of the inlet line, two hours seemed the minimum time required to stabilise the soil temperature to a new temperature.

For each temperature and COS concentration level, three inlet/outlet pairs were measured on each microcosm. This was done every 44 min to partially take the possible variability caused by the small water loss into account. Each line was measured for $120 \mathrm{~s}$ and only the last $15 \mathrm{~s}$ were retained to compute the mean COS concentration, accounting for the residence time of air in the tubing and gas analyser. The median standard deviation during these last $15 \mathrm{~s}$ was $12.4 \mathrm{ppt}$ for $\mathrm{COS}$ and $0.09 \mathrm{ppm}$ of $\mathrm{CO}_{2}$. From each inlet/outlet pair the net soil-to-air COS flux was computed as follows:

$F=\frac{\phi}{S}\left(c_{a}-c_{\text {in }}\right)$

where $F$ is the net COS flux (pmol m$\left.{ }^{-2} \mathrm{~s}^{-1}\right), \varphi$ is the flow rate of dry air through the chamber $\left(\mathrm{mol} \mathrm{s}^{-1}\right), S\left(0.00615 \mathrm{~m}^{2}\right)$ is the soil surface area, $c_{\text {in }}\left(\mathrm{pmol} \mathrm{mol}^{-1}\right)$ is the COS mixing ratio on the inlet and $c_{a}\left(\mathrm{pmol} \mathrm{mol}^{-1}\right)$ is the COS mixing ratio on the outlet. The air flow rate $\varphi$ was set at $0.250 \mathrm{nlpm}$, i.e. $186 \mu \mathrm{mol} \mathrm{s}^{-1}$. The COS flux for the blank chamber was never significantly different from zero.

The molar COS concentration $\left(C_{a}\right)$ was estimated from the molar ratio $\left(c_{a}\right)$ and soil temperature measurements using the ideal gas law and an air pressure of $106000 \mathrm{~Pa}$. The slight over pressure in the glass jars (of about $5 \mathrm{kPa}$ ) had been previously estimated during a preliminary experiment using a pressure transducer (BME280; Bosch GmbH, Gerlingen, Germany).

\subsection{Estimation of soil COS production and hydrolysis rates}

The COS production rate was first estimated on airdried soils at $18^{\circ} \mathrm{C}$ and under atmospheric concentration (ca. $500 \mathrm{ppt})$ levels of COS. This "dry" production rate $\left(P_{\mathrm{dry}}\right.$, pmol kg ${ }^{-1} \mathrm{~s}^{-1}$ ) was deduced from the COS flux (Eq. 4) according to

$P_{\text {dry }}=\frac{S F_{\text {dry }}}{M_{\text {dry }}}$,

where $M_{\text {dry }}(\mathrm{kg})$ is the mass of dry soil in the microcosm. The COS production and hydrolysis rates on fresh soils ( $P_{\text {moist }}$ and $k_{\text {moist }}$, respectively) were estimated using COS flux measurements performed at the three COS concentrations and Eqs. (2) and (3) described above. The linear relationship between $F$ and $C_{a}$ observed over a wide range of COS concentrations was confirmed using our set-up over the range of COS mixing ratios used in our experiments, i.e. 01200 ppt (see Supplement Fig. S3). These results justified the use of only three COS levels (referred to hereafter as "low", "med" and "high") to perform the linear regression and calculate $P_{\text {moist }}$ and $k_{\text {moist }}$ in subsequent analyses. Thus, the COS mixing ratio in the inlet airstream of each microcosm was set to $1111 \pm 29 \mathrm{ppt}$ ("high"), $557 \pm 10 \mathrm{ppt}$ ("med") or $124 \pm 8$ ppt ("low"), while the $\mathrm{CO}_{2}$ mixing ratio was maintained at around $399 \pm 6 \mathrm{ppm}$.

In order to evaluate whether the method used to estimate the COS production rate influenced the calculation of the COS hydrolysis rate of moist soils, we also used $P_{\text {dry }}$ to recalculate the hydrolysis rate of moist soils as in previous 


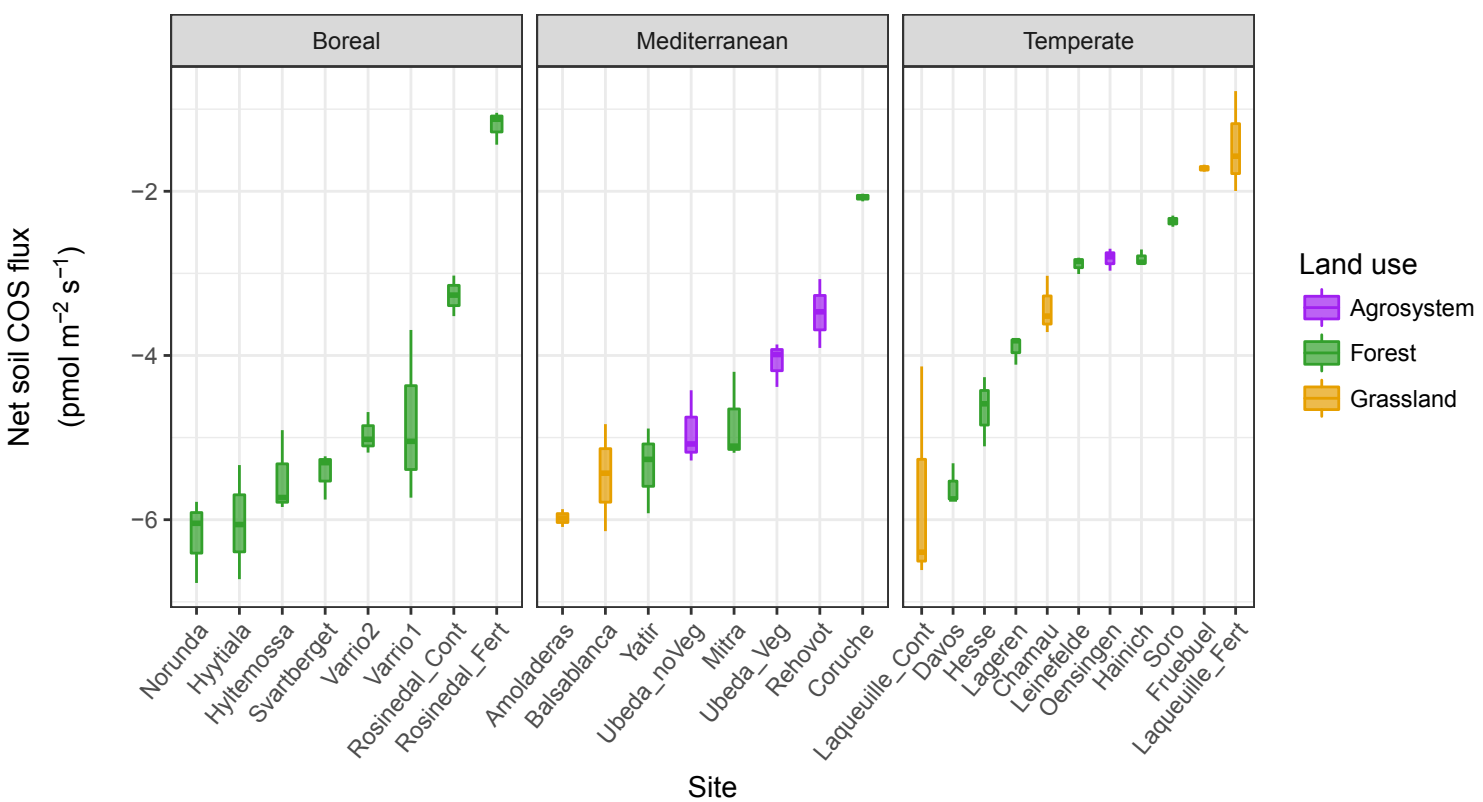

Figure 1. Variability in the net $\operatorname{COS}$ flux measured at $18^{\circ} \mathrm{C}$ and at an atmospheric COS concentration of 500 ppt on replicated $(n=3)$ moist (30\% WHC) soils sampled from across Europe and Israel (see Table 1). Net COS fluxes were not significantly different between biome or land use.

studies. To do so, we inserted $P_{\text {dry }}$ into Eq. (1) and solved for the hydrolysis rate that satisfied the equation for a given level of COS concentration (referred to as $k_{\text {recal, low }}, k_{\text {recal,med }}$ and $k_{\text {recal,high hereafter). }}$

The COS production and hydrolysis rates for the wet soils $\left(P_{\text {moist }}\right.$ and $\left.k_{\text {moist }}\right)$ were measured at two temperatures $(18$ and $\left.23^{\circ} \mathrm{C}\right)$ to estimate their temperature sensitivity $\left(Q_{10}\right)$ in this temperature range as follows:

$$
\begin{aligned}
& Q_{10}(k)=\left(\frac{k_{\text {wet }}\left(23^{\circ} \mathrm{C}\right)}{k_{\text {wet }}\left(18^{\circ} \mathrm{C}\right)}\right)^{2}, \\
& Q_{10}(P)=\left(\frac{P_{\text {wet }}\left(23^{\circ} \mathrm{C}\right)}{P_{\text {wet }}\left(18^{\circ} \mathrm{C}\right)}\right)^{2} .
\end{aligned}
$$

\subsection{Soil physico-chemical properties}

At the end of each gas exchange measurement, the soils were analysed for a range of physico-chemical properties. Soil texture and total $\mathrm{C}, \mathrm{N}$ and $\mathrm{CaCO}_{3}$ contents were measured using standard procedures at the INRA soil analyses platform (https://www6.hautsdefrance.inra.fr/las, last access: December 2016). Soil $\mathrm{pH}$ and redox potential were measured using a $1: 5 \mathrm{soil} /$ water ratio by a Fisher Scientific accumet $^{\mathrm{TM}}$ series XL250 dual Channel $\mathrm{pH} / \mathrm{mV}$ with a $\mathrm{pH}$ epoxy gel electrode, gelled redox platinum electrode and temperature probe. $\mathrm{pH}$ and redox electrodes were calibrated with buffer solutions $\mathrm{pH} \mathrm{4,} 7$ and 10 and with ORP solution $470 \mathrm{mV}$ from Hanna Instruments, respectively. Bulk density was estimated from the weight and volume of each soil microcosm. Soil water content was estimated gravimetrically as the weight differ- ence between moist and oven-dried soil extracts. The concentration of phosphate ions was measured as in Van Veldhoven and Mannaerts (1987). Microbial biomass for carbon (C) and nitrogen $(\mathrm{N})$ were estimated as the difference of dissolved $\mathrm{C}$ and $\mathrm{N}$ contents between fumigated $(24 \mathrm{~h}$ of chloroform fumigation) and non-fumigated soil extracts consisting of $10 \mathrm{~g}$ of soil mixed with $40 \mathrm{~mL}$ of $0.5 \mathrm{M} \mathrm{K}_{2} \mathrm{SO}_{4}$ and shaken for $30 \mathrm{~min}$.

\subsection{Statistical analyses}

All data processing and graphs were made using the R software (Version 3.3.3, R core Team, 2015) packages dplyr, lubridate, data.table and ggplot2. These were used to test the effects of biome and land use on the gross COS production $\left(P_{\text {moist }}\right)$ and first-order hydrolysis rate $\left(k_{\text {moist }}\right)$ constants, as well as assessing the effects of the atmospheric COS concentration on $k_{\text {recal,med }}$ and $k_{\text {moist }}$. The temperature response of $P_{\text {moist }}$ and $k_{\text {moist }}$ was compared using ANOVA and Tukey HSD tests. To investigate the correlation between soil properties and all COS fluxes (gross COS production and uptake, hydrolysis rate at $18^{\circ} \mathrm{C}$ ) Spearman correlations coefficients were calculated and tests for significance were performed with the corrplot package (Wei and Simko, 2017). 

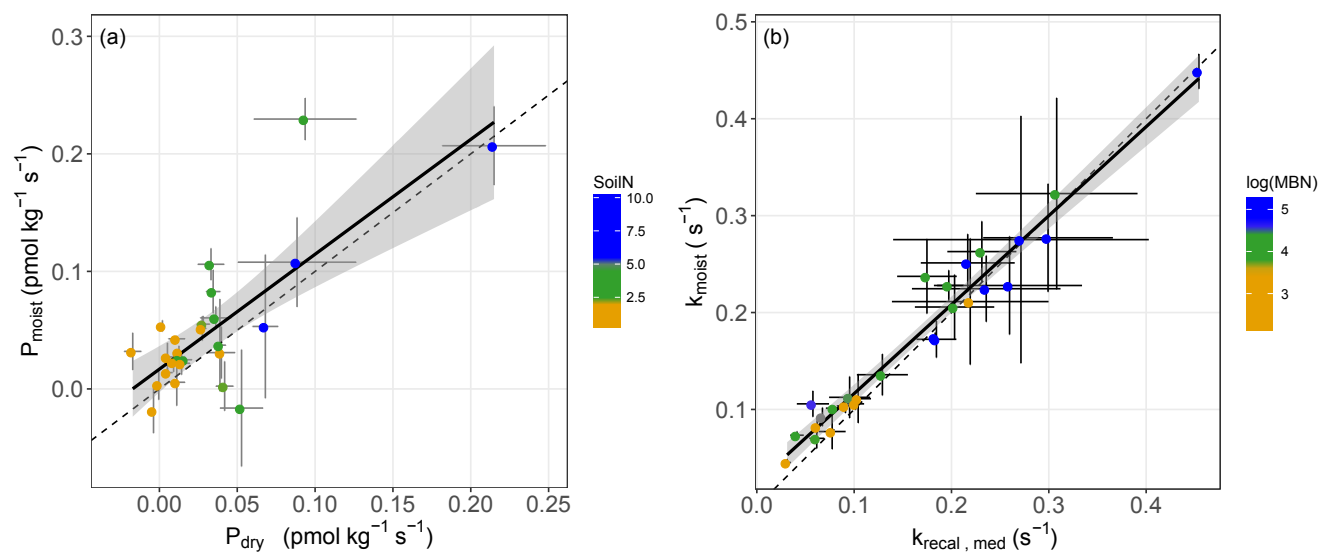

Figure 2. (a) Comparison of the soil COS production rates measured on air-dried soils $\left(P_{\text {dry }}\right.$; Method 1$)$ and moist soils $\left(P_{\text {moist }}\right.$; Method 2$)$ for the range of total soil nitrogen concentrations $\left(\mathrm{g} \mathrm{kg}^{-1}\right)$ measured at each site. (b) Comparison of the COS hydrolysis rate of moist soils ( $k_{\text {recal,med }}$ and $k_{\text {moist }}$, respectively) for the range of microbial biomass nitrogen $(\mathrm{MBN})\left(\mu \mathrm{g} \mathrm{g} \mathrm{g}^{-1}\right)$ at each site. Each point represents the mean flux \pm SD for each site measured at $18^{\circ} \mathrm{C}(n=3)$. The dashed lines represent the $1: 1$ slope, the solid black lines represent the slope of the linear models and the grey areas represent the $95 \%$ confidence level interval for predictions from the linear models.

\section{Results}

All moist soils were net $\operatorname{COS}$ sinks at $18^{\circ} \mathrm{C}$, with net fluxes ranging in magnitude from -7.66 to $-0.78 \mathrm{pmol} \mathrm{m}^{-2} \mathrm{~s}^{-1}$ (Fig. 1). In comparison, the blank was not significantly different from zero with mean net COS flux values of $-0.11 \pm 0.24 \mathrm{pmol} \mathrm{m}^{-2} \mathrm{~s}^{-1}$. Using the theoretical framework presented above we partitioned the net COS fluxes measured on moist soils to assess COS production and uptake rates and to compare moist $\left(P_{\text {moist }}\right)$ with dry $\left(P_{\text {dry }}\right)$ soil COS production rates. As illustrated in Fig. 2a the COS production rates measured on moist soils $\left(P_{\text {moist }}\right)$ were not significantly different from those measured on dry soils $\left(P_{\text {dry }}\right)$. Overall the relationship between $P_{\text {moist }}$ and $P_{\text {dry }}$ was highly significant $(P<0.001)$ and followed a linear regression slope of 0.98 with an intercept of $0.02 \mathrm{pmol} \mathrm{kg}^{-1} \mathrm{~s}^{-1}$ (Fig. 2a). Dispersion of data around the linear regression $\left(r^{2}=0.59\right)$ indicated that some soils were occasionally underestimated by one method compared to the other. Upon investigation we found that some soils, having much higher $P_{\text {moist }}$ than $P_{\text {dry }}$, may not have air-dried completely dry. This hypothesis is partially supported by the persistence of a small net $\mathrm{CO}_{2}$ flux (Table $\mathrm{S} 1$ in the Supplement) for these soils, indicating that some uptake of COS could still possibly be contributing to some of the dispersion in the data.

Our study also indicated that the rates of COS production from moist soils measured at $18^{\circ} \mathrm{C}\left(P_{\text {moist }}\right)$ were significantly higher in temperate regions compared to those measured in boreal and Mediterranean regions (ANOVA $P=$ 0.0009 , Tukey HSD tests: temperate-Mediterranean $P=$ 0.0009 , temperate-boreal $P=0.03$, Mediterranean-boreal $P=0.4$; Figs. 3 and S4). The highest COS production rates were measured on soils coming from temperate grassland sites (Figs. 3 and S4). Further analysis indicated that the eight temperate soils exhibiting the highest COS production rates also contained high $\mathrm{C}$ and $\mathrm{N}$ contents (Fig. 2a). The total $\mathrm{C}$ and $\mathrm{N}$ contents of the different soils were positively correlated with high microbial $\mathrm{C}$ and $\mathrm{N}$ biomass as well as redox potential, whilst negatively correlated with bulk density (Figs. 4 and S5 and Table S1). In addition, the total $\mathrm{N}$ content was further correlated with site mean annual precipitation (MAP) (Fig. 4). No significant effect was detected between $P_{\text {moist }}$ and latitude, longitude or land use cover. However, COS production rates were significantly and positively correlated with soil N content $(r=0.52)$, MAP $(r=0.53)$ and soil redox potential $(r=0.50)$ and negatively correlated with $\mathrm{pH}(r=-0.41)$ (Fig. 4). However, a principle component analysis indicated that the production rate was most closely associated with soil $\mathrm{N}$ content (Fig. S5).

The partitioned gross COS uptake rates $\left(V_{\mathrm{d} 0} C_{a}\right)$ measured at $30 \%$ WHC were always much larger in absolute values (between -7.66 and $-1.34 \mathrm{pmol} \mathrm{m}^{2} \mathrm{~s}^{-1}$ ) than the COS production rates $P_{\text {moist }}$ (less than $0.81 \mathrm{pmol} \mathrm{m}^{2} \mathrm{~s}^{-1}$ ); thus, the COS uptake rates dominated the net COS flux $F$ (Fig. 3). The first-order COS hydrolysis rate constant $k_{\text {moist }}$ was estimated to vary between 0.05 and $0.47 \mathrm{~s}^{-1}$ and the relationship between the two estimates, $k_{\text {moist }}$ and $k_{\text {recal,mid, was strongly }}$ $\left(r^{2}=0.96\right)$ and linearly interconnected, exhibiting a slope and intercept of 0.94 and $0.02 \mathrm{~s}^{-1}$, respectively (Fig. 2b). Thus, demonstrating that the use of $P_{\text {moist }}$ or $P_{\text {dry }}$ had little influence on the retrieval of the first-order COS hydrolysis rate constants (Fig. 2b). However, the relative difference between the COS hydrolysis rates $k_{\text {moist }}$ and those recalculated using $P_{\text {dry }}$ and Eq. (1) were significantly different when measured at different COS concentrations (Fig. 5; $P=0.002$ ). Indeed, the COS hydrolysis rate that satisfied the equation for low COS concentrations, $k_{\text {recal,low }}$ (estimated using $F$ and $C_{a}$ data from the low $\operatorname{COS}$ concentration measurements), 


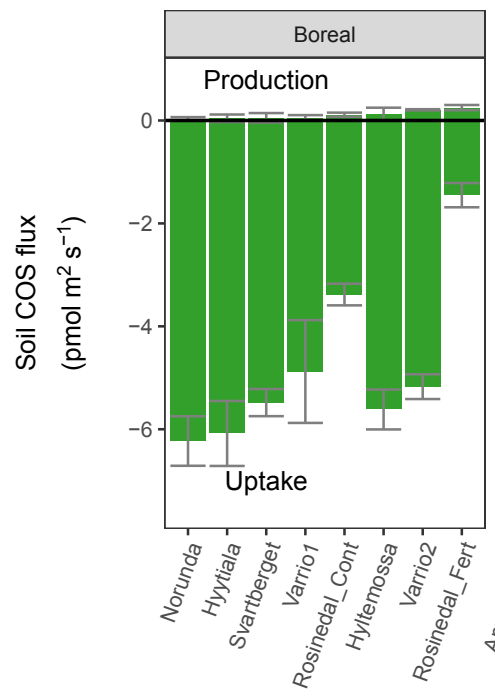

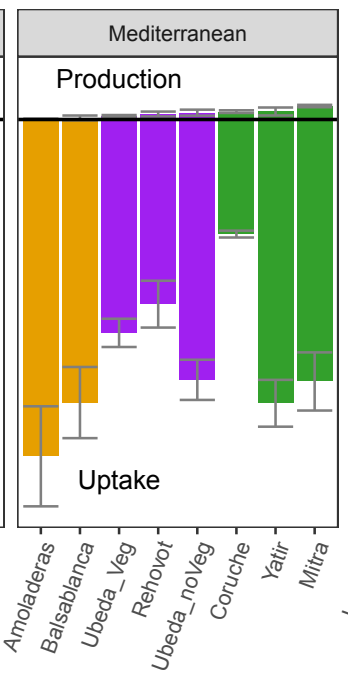

Site

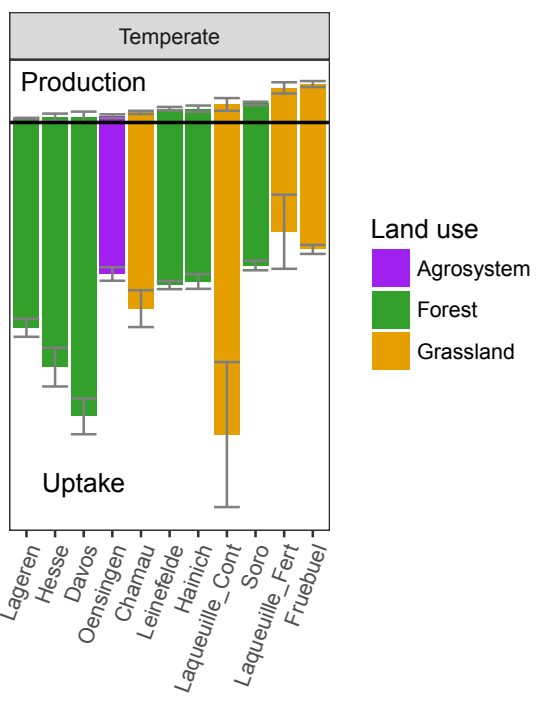

Figure 3. Partitioned mean $( \pm \mathrm{SD})$ gross $\mathrm{COS}$ production and COS uptake rates estimated from the measured net COS flux of soils incubated at $18^{\circ} \mathrm{C}$ and at an atmospheric COS concentration of $500 \mathrm{ppt}$ on moist soils; values are ranked by biome and by COS production rate in ascending order $(n=3)$ for each of the 27 sites sampled in Europe and Israel. Rosinedal_Fert and Laqueuille_Fert are experimental plots intensively fertilised with nitrogen as part of a manipulation experiment. Ubeda_Veg and Ubeda_noVeg represent soils sampled in the same location but with or without vegetation, respectively.

was significantly $(P=0.0011)$ lower than that estimated at high COS concentration, $k_{\text {recal, high }}$ (estimated using $F$ and $C_{a}$ data from the high COS concentration measurements). However, $k_{\text {recal,mid }}$ (estimated using the medium COS concentration measurements) was intermediate and not significantly different from either $k_{\text {recal, high }}(P=0.52)$ or $k_{\text {recal, low }}$ $(P=0.056)$. Furthermore, $k_{\text {recal, low values exhibited a larger }}$ spread in the deviation from $k_{\text {moist }}$ than both $k_{\text {recal,mid }}$ and

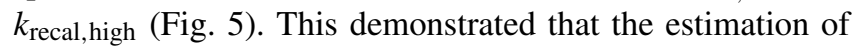
the COS hydrolysis rate using Eq. (1) becomes more sensitive to the value of $P$ prescribed when flux measurements are performed at low COS concentrations, as there is a decrease in the fraction of COS uptake with respect to COS production. In contrast to the results found for the COS production rates, the first-order COS hydrolysis rate constants $k_{\text {moist }}$ were not related to land use or biome. However, $k_{\text {moist }}$ values were positively and significantly correlated with microbial $\mathrm{N}$ $(r=0.64)$ and $\mathrm{C}(r=0.45)$ biomass contents (Fig. 4$)$.

The temperature sensitivity $\left(Q_{10}\right)$ of $P_{\text {moist }}$ had a mean and standard deviation of $4.36 \pm 4.45$. This was significantly higher $(P<0.0001)$ than the $Q_{10}$ of the hydrolysis rate that had a mean and standard deviation of $1.26 \pm 0.29$ (Fig. 6). The variability in $Q_{10}$ values across the 27 soils was also much larger for COS production rates than for COS hydrolysis rates. The temperature sensitivity of $P_{\text {moist }}$ did not correlate with any of the measured soil properties (Fig. 4). However, the $Q_{10}$ values of the COS hydrolysis rate constants were significantly and negatively correlated with soil total C content $(r=-0.46)$ and positively correlated to bulk density $(r=0.32)$ (Fig. 4).

\section{Discussion}

\subsection{COS production rates measured on dry soils are a reasonable proxy for $\mathrm{COS}$ production rates in moist soils}

Net COS fluxes measured from oxic soils commonly exhibit a unimodal response to water-filled pore space (WFPS) (Kesselmeier et al., 1996; Van Diest and Kesselmeier, 2008; Whelan et al., 2017). Recently a theoretical framework was advanced describing how WFPS influences the diffusion of $\mathrm{COS}$ in the soil matrix and how this partially regulates the rate of COS hydrolysis by the enzyme CA in addition to temperature and COS concentration (Ogée et al., 2016). Guided by this theoretical framework, we estimated that by maintaining moisture levels in our soils at $\sim 30 \%$ water holding capacity we would be conducting our experiments very close to the optimum WFPS (between 15 to $37 \%$ ) for gross COS uptake. However, it was not clear whether COS production would also respond to variable soil water content. As it is much easier and convenient to store dry soil and take measurements in the laboratory we felt it was important to test this assumption, which had the possibility of opening up a greater spatial characterisation of soil COS production rates if dry soil was demonstrated to be a robust proxy for COS production rates at optimum WFPS conditions. In general, 


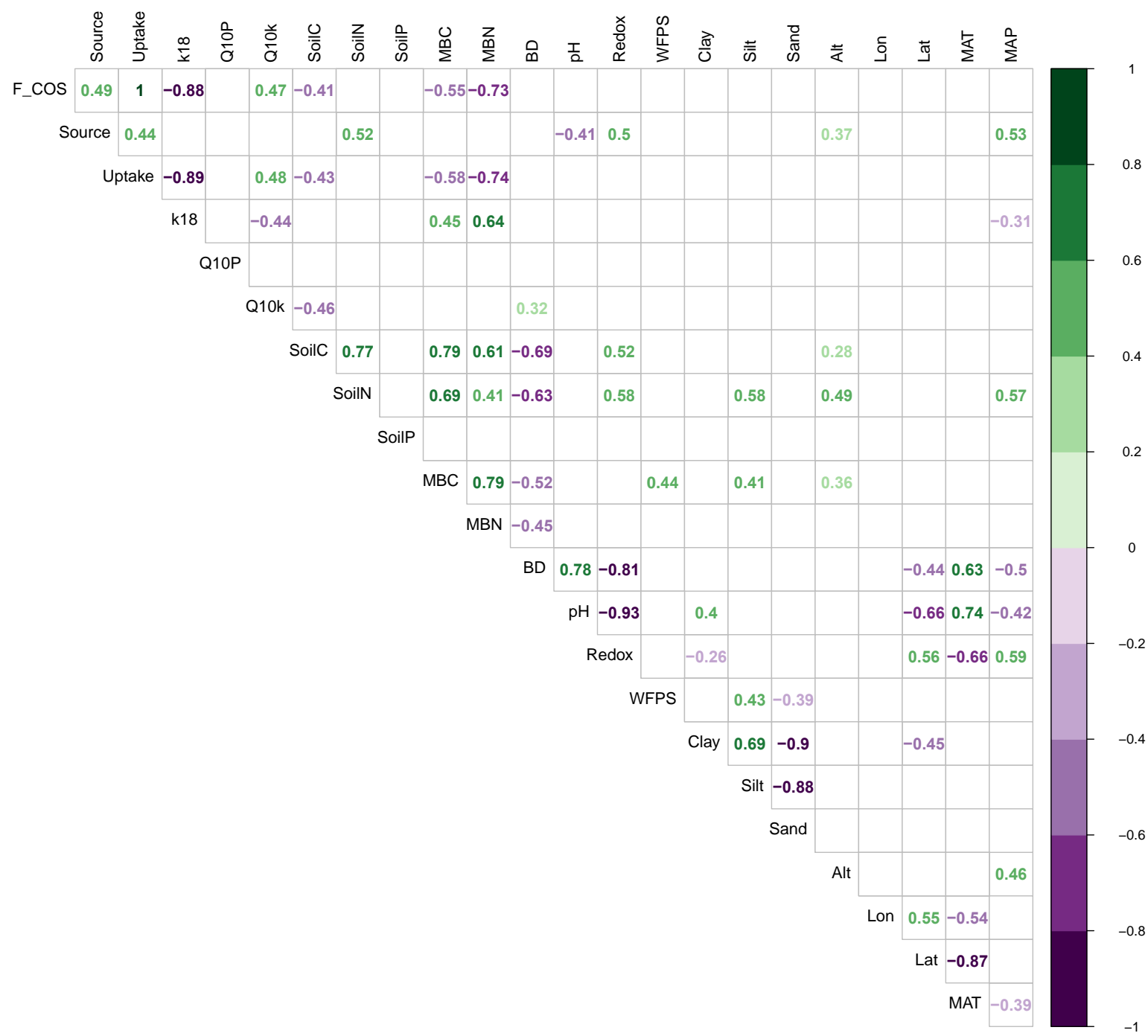

Figure 4. Spearman correlation coefficients (rho) between variables describing soil COS fluxes and soil properties. "F_COS" is the net COS flux at $18^{\circ} \mathrm{C}$, "Source" is the gross COS production rate at $18{ }^{\circ} \mathrm{C}$, "Uptake" is the gross COS uptake rate at $18^{\circ} \mathrm{C}$, " $k 18$ " is the hydrolysis rate constant at $18^{\circ} \mathrm{C}$, " $Q_{10 P}$ " and " $Q_{10 k}$ " are the $Q_{10}$ of the source and the hydrolysis rate, "SoilP", "SoilC" and "SoilN" are the respective soil phosphate $(\mathrm{P}), \mathrm{C}$ and $\mathrm{N}$ content, "MBC" and "MBN" are the respective microbial biomass $\mathrm{C}$ and $\mathrm{N}$ contents, "BD" is the bulk density, "Redox" is the potential redox, "WFPS" is the water filled pore space, "Alt" is the site altitude, "Lon" is the site longitude, "Lat" is the site latitude and "MAT" and "MAP" are the respective mean annual temperature and precipitation for each site. Only significant correlations are shown $(P<0.05)$.

the experimental results supported the use of dry soil COS production rates to confidently infer COS production rates in moist soils at optimal moisture conditions (Fig. 2a). In addition, a recent study by Bunk et al. (2017) measuring the net COS flux of a tropical soil over a range of WHC (between 3 and $90 \%$ ) also showed that the COS production rate (estimated as the net COS flux measured after a fungicide treatment) was not responsive to soil moisture variations; therefore, providing support for our experimental results. However, in contrast Bunk et al. (2017) also reported that a temperate agricultural soil exhibited a soil moisture response that they attributed to variations in the COS production flux rate, in contradiction to the current theory presented in Eq. (1). Indeed when the hydrolysis rate constant tends to zero $(k \rightarrow 0)$, Eq. (1) simplifies to $F=\rho_{\mathrm{b}} P / z_{\max }$ so that the net COS flux $F$ should become independent of soil moisture, provided $P$ does not respond to soil moisture. Thus, to reconcile the results from Bunk et al. (2017) with theory, we would need to invoke a partial and/or non-uniform inhibition of $k$ via fungicide application (used to infer the production rate effect). A non-uniform reduction of soil moisture upon drying could also create a soil moisture response without the need to evoke a dependence of $P$ on soil water availability. Interestingly, if we extrapolate the results of Bunk et al. (2017) 


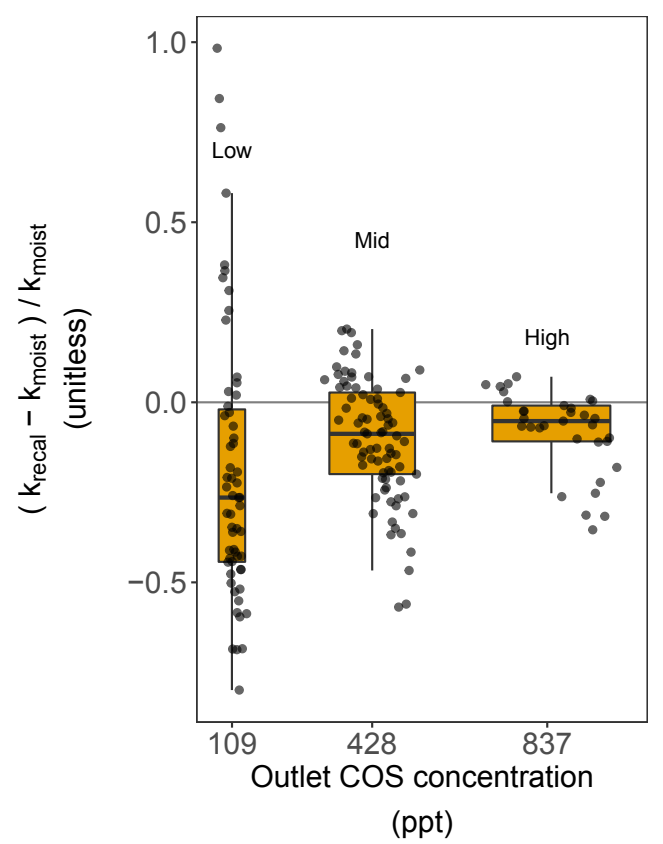

Figure 5. Difference in the COS hydrolysis rate constants of moist soils, calculated using the production rates estimated from dried soils $\left(k_{\text {recal }}\right.$ with $\left.P_{\text {dry }}\right)$ and moist soils $\left(k_{\text {moist }}\right.$ with $\left.P_{\text {moist }}\right)$, as a function of three different atmospheric COS concentrations in the outlet. Each grey point represents one soil replicate, the red box shows the lower, median and upper quartile values, the whiskers indicate the range of variation in the difference, and the box width represents the range of variation in the net COS flux measured for the different soils.

at $0 \% \mathrm{WHC}$, the (fully dry) net COS flux would correspond reasonably well to the fungicide-inhibited flux measured at $30 \% \mathrm{WHC}$, and would completely corroborate the results presented in the current study (Fig. 2a).

Furthermore, our study showed that when using Eq. (1) and assuming $P_{\mathrm{dry}}$ as a proxy for $P$ to estimate the COS hydrolysis rate constant $k$, the uncertainty of $k$ increased at lower atmospheric COS concentrations (Fig. 5). This is because, as the atmospheric COS concentration decreases, the contribution of the sink term to the overall net COS flux becomes progressively smaller. In addition and more importantly, this increased uncertainty was biased towards smaller $k$ values (Fig. 5), with the median $k$ value significantly lower (by around $20 \%$ ) at ca. $100 \mathrm{ppt}$ compared to that obtained at ca. 800 ppt. Even at ca. $800 \mathrm{ppt}$, the recalculated $k\left(k_{\text {recal,high }}\right)$ was still smaller on average than $k_{\text {moist }}$ (Fig. 2b). In addition, it is worth noting that the bias between $k_{\text {recal }}$ and $C_{a}$ cannot be explained by Michaelis-Menten kinetics. Indeed, according to such an enzymatic model, $k$ should remain constant for $C_{a} \ll K_{m}$ and should decrease, not increase, at higher $C_{a}$ concentrations. Thus, overall, our results suggest that studies using $P_{\text {dry }}$ (Whelan et al., 2016) can provide a good proxy of $P$ in moist conditions; however, this may lead to a small

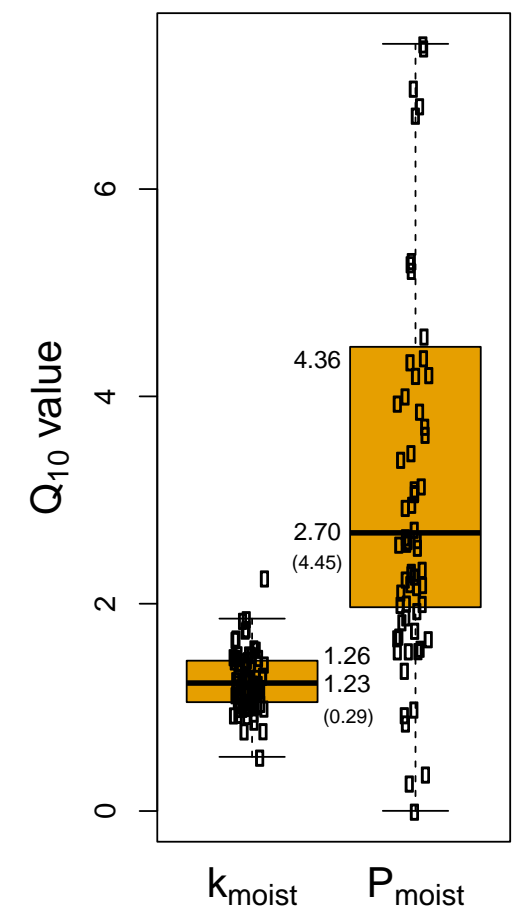

Figure 6. The estimated temperature sensitivity $\left(Q_{10}\right)$ of COS production $\left(P_{\text {moist }}\right)$ and hydrolysis rate $\left(k_{\text {moist }}\right)$ across 27 sites in Europe and Israel. Each point represents the estimated parameter for each of the three replicated microcosms incubated at two temperatures from all sites. The box indicates the lower, median and upper quartile values, the whiskers show the range of variation in the difference and display the mean (SD) and median value for the $Q_{10}$ parameter.

and probably insignificant underestimation of the COS uptake rate constant if measurements are made over the same range of COS concentrations tested in our study.

\subsection{Soils generally act as COS sinks at cool temperatures but rapidly become COS sources upon warming}

Across a range of biome and land use types we found that the relative contribution of $\mathrm{COS}$ production to the net soil COS flux was generally smaller than the $\operatorname{COS}$ uptake rate at $18^{\circ} \mathrm{C}$, but increased at higher temperatures $\left(23^{\circ} \mathrm{C}\right)$ and lower atmospheric COS concentrations. At COS concentrations close to those found in the atmosphere $(\sim 500 \mathrm{ppt})$, net COS fluxes were always negative in our soils when measured at $18^{\circ} \mathrm{C}$, indicating that the compensation point (i.e. the COS concentration at which the net flux is zero) was always below the atmospheric COS concentration. Even at $100 \mathrm{ppt}$, only five of the soils had positive net COS fluxes indicating that the COS compensation point was generally lower than $100 \mathrm{ppt}$ for the majority of the soils. This is consistent with previous studies on oxic soils (Kesselmeier et al., 1999; Liu et al., 2010) but contradictory to the results of Lehman and 
Conrad (1996) who found much higher compensation points. This apparent contradiction might be explained by the much higher and wider range of COS concentrations (60-410 ppb) explored by Lehmann and Conrad (1996), where different COS consumption processes might take place (e.g. physiosorption; Conrad and Meuser, 2000). There are further studies conducted in sub-tropical humid monsoon climates that have also reported COS compensation points above $100 \mathrm{ppt}$ (Geng and Mu, 2004; Yi and Wang, 2011), but still below atmospheric concentrations (i.e. around $300 \mathrm{ppt}$ ). These higher compensation points might be explained by the warmer temperatures expected in this type of climate that should favour COS production over consumption (Fig. 6); therefore, shifting the compensation point to higher COS concentration values and even causing some soils to become net COS emitters. Because the temperature sensitivity of the production rate is always larger than that of the hydrolysis constant, a potential shift in the optimum temperature of COS uptake would not be enough to offset the larger production rates at the higher temperatures. This relatively greater temperature sensitivity of COS production rates found in our experiment are also consistent with a number of previous studies reporting the temperature sensitivities $\left(Q_{10}\right)$ of production-dominated net COS soil fluxes in the range of 1.7 to 3.3 (Maseyk et al., 2014; Saito et al., 2002; Whelan and Rhew, 2015, 2016). Altogether, our results show that soil COS production (and its contribution to the net COS flux) varies across different biomes and temperature regimes and must be accounted for when performing atmospheric COS budgets.

\subsection{Soil COS production rates increase with soil $N$ content and mean annual precipitation}

Currently, COS emissions by oxic soils are considered to be abiotic in origin (Kitz et al., 2017; Whelan and Rhew, 2015). Dramatic COS production rates have been observed across American and Chinese agricultural soils (Billesbach et al., 2014; Liu et al., 2010; Maseyk et al., 2014; Whelan and Rhew, 2015). However, the exact mechanisms underlying COS production are still under debate (Whelan et al., 2016). A number of hypotheses including the thermal degradation of soil organic matter or desorption of COS from soil surfaces have been proposed and are partially supported by the persistence of COS emissions after autoclaving (Kato et al., 2008; Whelan and Rhew, 2015; Whelan et al., 2016). Another abiotic process that could lead to COS production is the chemical reaction that occurs in flue gas from molecules present during combustion such as $\mathrm{CH}_{4}+\mathrm{SO}_{2} \Leftrightarrow \mathrm{COS}+\mathrm{H}_{2} \mathrm{O}+\mathrm{H}_{2}$ (Rhodes et al., 2000). Both sulfur dioxide $\left(\mathrm{SO}_{2}\right)$ and methane $\left(\mathrm{CH}_{4}\right)$ can be produced in soils, however $\mathrm{CH}_{4}$ is generally produced in anaerobic zones of submerged soils and tends not to accumulate at the soil surface (Le Mer and Roger, 2001). Thus, it is not clear whether this reaction would be possible in aerobic, dry soils and maintain the same rate when moist. The thermal decomposition of $\mathrm{CH}_{3} \mathrm{SCO}$ radi- cals (Barnes et al., 1994) and the oxidation of thioformaldehyde and DMS (Barnes et al., 1996) present other reactions that could lead to the production of COS. However, these two reactions are unlikely to explain our results from darkincubated soils, as both reactions require the photolysis or photoproduction of certain compounds for the reaction to proceed.

Conversely, there is growing evidence that biotic processes may also contribute to COS emission rates (Whelan et al., 2017). In particular a number of studies provide direct evidence for the production of COS during the hydrolysis of thiocyanates when catalysed by thiocyanate hydrolase, an enzyme found in a range of bacteria (Katayama et al., 1992; Kim and Katayama, 2000; Ogawa et al., 2013) and a few fungi (Masaki et al., 2016). If COS production rates were even partially driven by such biotic processes, this contribution might be sensitive to soil water content and be expected to decrease at very low soil water contents as microbial activity tends to slow down and microbes enter either a stationary growth phase and/or a dormant state (Roszak and Colwell, 1987). However, we did not observe any significant reduction in COS production rates after air drying of the soils (Fig. 2a). One potential explanation for this could be that some microorganisms can persist for prolonged periods of time in drought conditions, utilising energy reserves at a very slow rate (Raubuch et al., 2002) but nonetheless remain metabolically active (Manina and McKinney, 2013). For example, Zoppini and Marxsen (2010) demonstrated that some extracellular activities in river sediments were not reduced even after one year of drying. This can arise as air-dried soils can still contain some residual water in soil micropores that maintains enzymatic activity. The amount of liquid water required for maintaining such biological activity, including thiocyanate hydrolase activity, could be extremely small and would still result in a detectable amount of COS being emitted. In addition, Maire et al. (2013) showed that endoenzymes released from dead organisms were stabilised in soils and could still lead to extracellular oxidative metabolism. This could also partly explain the continuation of COS production even at very low water content in our soils. In this context, even sterilised (autoclaved) soils might still produce COS as microbial death can release nutrients and intracellular metabolites into the soil environment, including endoenzymes capable of resisting the autoclaving process. Although our results cannot rule out any of the above mechanistic hypotheses, our conclusions and those from previous studies indicate that the COS emission rates of air-dried and autoclaved soils are related to past biotic activity and in particular the soil nitrogen status. Our study showed that the magnitude of COS emitted from soils was positively correlated to total $\mathrm{N}$ concentration (Figs. 2a and 4) over a range of soil $\mathrm{N}$ concentrations between 0.38 and $10.2 \mathrm{~g} \mathrm{~kg}^{-1}$ (Table S2). Although this is the first study to demonstrate a significant relationship between soil $\mathrm{N}$ concentration and gross COS production rates, previous studies have measured shifts 
in the magnitude of net $\mathrm{COS}$ and $\mathrm{CS}_{2}$ fluxes upon fertilisation with nitrate in both deciduous and evergreen coniferous forests (Melillo and Steudler, 1989). In addition, a number of studies on agricultural soils (typically fertilised) in the US and China have observed large temperature-sensitive emissions of COS (Billesbach et al., 2014; Liu et al., 2010; Maseyk et al., 2014; Whelan and Rhew, 2015). Currently, the mechanism(s) for the observed increase in COS production rates with increasing $\mathrm{N}$ content in soils is clearly not understood. However, it is known that sulfur (S)-containing amino acids such as methionine, cystine and cysteine are all potential precursors of $\mathrm{COS}$ and $\mathrm{CS}_{2}$ formation (Bremner and Steele, 1978; Minami and Fukushi, 1981a, b) and could be abiotically degraded, for example in the presence of ozone (Sharma and Graham, 2010) or light (Whelan and Rhew, 2015). However, all measurements in our study were conducted in the dark, which eliminates this latter mechanism as a potential driver of our results. Thus, ecosystems exposed to higher nitrogen inputs, either naturally or by enhanced fertilisation, may be creating plant and soil organic matter that contains relatively more $\mathrm{N}$ - and S-containing precursors such as amino acids and proteins that then become available substrates in soils for temperature-sensitive abiotic degradation. Further studies investigating the link between soil $\mathrm{N}$ inputs and soil COS fluxes would be useful to assess whether total soil $\mathrm{N}$ and soil microbial $\mathrm{N}$ biomass traits could be helpful integrated predictors of how respective soil COS production and uptake rates vary across large spatial scales, irrespective of whether the underlying mechanism of COS production is abiotic or biotic in nature. Meanwhile, parallel studies clarifying the mechanistic processes underlying the production will aid the development of models attempting to dynamically describe the instantaneous exchange between soils and the atmosphere and their link to climate, vegetation type and management regime.

\subsection{Soil COS uptake rate constant increases with soil microbial content and displays a small temperature sensitivity}

Direct evidence for the role of carbonic anhydrase (CA) in the uptake of COS has been established in past lab experiments with plant extracts (Protoschill-Krebs et al., 1996), and indirect evidence has been found in soils treated with CA inhibitors (Kesselmeier et al., 1999). Based on the theoretical framework that exists for the catalysis of $\mathrm{CO}_{2}$ uptake by CA in soils (Wingate et al., 2010; Sauze et al., 2018), Ogée et al. (2016) developed an analogous framework to describe the uptake of COS by CA in soils (Eq. 1) and was able to reproduce the observed response of the net and gross COS uptake rate with water-filled pore space and its optimum. Our study unequivocally suggests that the response of the net COS uptake to soil water content is dominated by changes in the gross COS uptake, not the COS production rate, which is in agreement with Eq. (1).
An important parameter in this modelling framework is the temperature sensitivity $\left(Q_{10}\right)$ of the CA-catalysed COS hydrolysis rate $k$. In this study a mean value of $1.23 \pm 0.29$ was estimated for the $Q_{10}$ of $k_{\text {moist }}$ over the entire range of 27 soils and it exhibited much lower variability than the temperature sensitivity response of gross COS production (Fig. 6). Although the range of $Q_{10}$ for the hydrolysis rate was linearly and negatively related to soil C content (Fig. 4), this parameter appeared fairly conservative amongst the different soils; the $Q_{10}$ mean value was also consistent with a range of published $Q_{10}$ values (1.22 to 1.9) for plant CA extracts (Burnell and Hatch, 1988; Boyd et al., 2015; Ogée et al., 2016), reinforcing the idea that the uptake of COS by the soils studied is driven by CA activity.

The large scale variability in the COS hydrolysis rate (at a given temperature and $30 \% \mathrm{WHC}$ ) was mostly related to variations in microbial $\mathrm{C}$ and $\mathrm{N}$ biomass (Fig. 4), and the majority of the smaller COS hydrolysis rates were indeed found in soils with the lowest microbial biomass. This result is consistent with the model from Ogée et al. (2016) that proposes soil CA activity to vary proportionally to the total volume of all the microbes present in a soil, provided that their CA requirements are similar. Our study, in addition to two further field studies (Saito et al., 2002; Yi et al., 2007), provide support for such a hypothesis, although differences in pH (Ogée et al., 2016; Sauze et al., 2018) and microbial community structure (Sauze et al., 2018) may complicate the relationship between the COS uptake rate constant and microbial biomass.

\section{Conclusions}

Uncertainties regarding the contribution of oxic soils to the atmospheric mass balance are large, with estimates for the global soil sink strength varying from 70 to $510 \mathrm{GgS} \mathrm{yr}^{-1}$ (Berry et al., 2013; Campbell et al., 2017; Launois et al., 2015; Montzka et al., 2007; Suntharalingam et al., 2008). Although developments in the mechanistic understanding and modelling of soil-atmosphere COS have been made recently (Ogée et al., 2016; Sun et al., 2016), it still remains a challenge to extend the observations of a limited set of experimentally different datasets to robust descriptions of soilatmosphere COS exchange in land surface models. This lack of coherently collected data across multiple biomes and land use types currently hinders advances in modelling the variability in atmospheric COS concentrations on a large scale. Our study goes some way towards addressing this gap by providing a comprehensive dataset of partitioned COS fluxes across Europe and Israel, alongside the prominent soil characteristics that are commonly measured and mapped, providing potential transfer functions that can translate soil physical and chemical properties into globally gridded maps of COS production and uptake rates by soils. In particular we showed that COS hydrolysis rates were linked to microbial 
$\mathrm{C}$ biomass, whilst COS production rates were linked to soil $\mathrm{N}$ content and MAP. In addition both of these gross COS fluxes exhibited distinctly different temperature and moisture sensitivities. These different soil proprieties should now be explored more deeply to determine their added value in the prediction of soil COS fluxes and their ability to reconcile the contribution of soil COS fluxes to the atmospheric COS budget.

Data availability. The underlying research data are part of European Research Council grant no. 338264 and will be made publicly accessible at the end of the grant. In the meantime the data may be requested from the corresponding author by email.

Supplement. The supplement related to this article is available online at: https://doi.org/10.5194/acp-18-9425-2018-supplement.

Author contributions. AK, JO, LW and JS designed the experiments and AK, JS, SW, SJ and AG carried them out. AK prepared the manuscript with contributions from JO and LW.

Competing interests. The authors declare that they have no conflict of interest.

Acknowledgements. This project has received funding from the European Research Council (ERC) under the European Union's Seventh Framework Programme (FP7/2007-2013) (grant agreement No. 338264, awarded to Lisa Wingate), the French Agence Nationale de la Recherche (ANR) (grant agreement No. ANR-13-BS06- 0005-01) and the Institut National de la Recherche Agronomique (INRA) departments EFPA and EA (PhD studentship for Joana Sauze). We are also grateful to all the scientific teams across Europe and Israel that provided their valuable time to collect soil samples from their local experimental sites for this study, especially Jorge Curiel-Yuste, Alexandria Correia, Jean-Marc Ourcival, Jukka Pumpanen, Huizhong Zhang, Carmen Emmel, Nina Buchmann, Sabina Keller, Irene Lehner, Anders Lindroth, Andreas Ibrom, Jens Schaarup Sorensen, Dan Yakir, Fulin Yang, Michal Heliasz, Susanne Burri, Penelope Serrano Ortiz, Maria Rosario Moya Jimenez, Jose Luis Vicente, Holger Tulp, Per Marklund, John Marshall, Nils Henriksson, Raquel Lobo de Vale, Lukas Siebicke, Bernard Longdoz, Pascal Courtois and Katja Klumpp.

Edited by: Marc von Hobe

Reviewed by: Mary E. Whelan and one anonymous referee

\section{References}

Barnes, I., Becker, K. H., and Patroescu, I.: The tropospheric oxidation of dimethyl sulfide: A new source of carbonyl sulfide, Geophys. Res. Lett., 21, 2389-2392, https://doi.org/10.1029/94GL02499, 1994.

Barnes, I., Becker, K. H., and Patroescu, I.: FTIR product study of the $\mathrm{OH}$ initiated oxidation of dimethyl sulphide: Observation of carbonyl sulphide and dimethyl sulphoxide, Atmos. Environ., 30, 1805-1814, https://doi.org/10.1016/1352-2310(95)00389-4, 1996.

Berry, J., Wolf, A., Campbell, J. E., Baker, I., Blake, N., Blake, D., Denning, A. S., Kawa, S. R., Montzka, S. A., Seibt, U., Stimler, K., Yakir, D., and Zhu, Z.: A coupled model of the global cycles of carbonyl sulfide and $\mathrm{CO}_{2}$ : A possible new window on the carbon cycle, J. Geophys. Res.-Biogeo., 118, 842-852, https://doi.org/10.1002/jgrg.20068, 2013.

Billesbach, D. P., Berry, J. A., Seibt, U., Maseyk, K., Torn, M. S., Fischer, M. L., Abu-Naser, M., and Campbell, J. E.: Growing season eddy covariance measurements of carbonyl sulfide and $\mathrm{CO}_{2}$ fluxes: $\mathrm{COS}$ and $\mathrm{CO}_{2}$ relationships in Southern Great Plains winter wheat, Agr. Forest Meteorol., 184, 48-55, https://doi.org/10.1016/j.agrformet.2013.06.007, 2014.

Boyd, R. A., Gandin, A., and Cousins, A. B.: Temperature Responses of $\mathrm{C} 4$ Photosynthesis: Biochemical Analysis of Rubisco, Phosphoenolpyruvate Carboxylase, and Carbonic Anhydrase in Setaria viridis, Plant Physiol., 169, 1850-1861, https://doi.org/10.1104/pp.15.00586, 2015.

Borchers, H. W.: pracma: Practical Numerical Math Functions, $\mathrm{R}$ package version 2.0.7, available at: https://cran.r-project.org/ web/packages/pracma/index.html, last access: 22 June 2017.

Bremner, J. M. and Steele, C. G.: Role of Microorganisms in the Atmospheric Sulfur Cycle, in: Advances in Microbial Ecology, Springer, Boston, MA, 155-201, 1978.

Bunk, R., Behrendt, T., Yi, Z., Andreae, M. O., and Kesselmeier, J.: Exchange of carbonyl sulfide (OCS) between soils and atmosphere under various $\mathrm{CO}_{2}$ concentrations, J. Geophys. Res.-Biogeo., 122, 2016JG003678, https://doi.org/10.1002/2016JG003678, 2017.

Burnell, J. N. and Hatch, M. D.: Low Bundle Sheath Carbonic Anhydrase Is Apparently Essential for Effective C4 Pathway Operation, Plant Physiol., 86, 1252-1256, https://doi.org/10.1104/pp.86.4.1252, 1988.

Brühl, C., Lelieveld, J., Crutzen, P. J., and Tost, H.: The role of carbonyl sulphide as a source of stratospheric sulphate aerosol and its impact on climate, Atmos. Chem. Phys., 12, 1239-1253, https://doi.org/10.5194/acp-12-1239-2012, 2012.

Campbell, J. E., Berry, J. A., Seibt, U., Smith, S. J., Montzka, S. A., Launois, T., Belviso, S., Bopp, L., and Laine, M.: Large historical growth in global terrestrial gross primary production, Nature, 544, 22030 https://doi.org/10.1038/nature22030, 2017.

Castro, M. S. and Galloway, J. N.: A comparison of sulfurfree and ambient air enclosure techniques for measuring the exchange of reduced sulfur gases between soils and the atmosphere, J. Geophys. Res., 96, 15427-15437, https://doi.org/10.1029/91JD01399, 1991.

Conrad, R.: Compensation concentration as critical variable for regulating the flux of trace gases between soil and atmosphere, Biogeochemistry, 27, 155-170, https://doi.org/10.1007/BF00000582, 1994.

Conrad, R. and Meuser, K.: Soils contain more than one activity consuming carbonyl sulfide, Atmos. Environ., 34, 3635-3639, https://doi.org/10.1016/S1352-2310(00)00136-9, 2000. 
de Mello, W. Z. and Hines, M. E.: Application of static and dynamic enclosures for determining dimethyl sulfide and carbonyl sulfide exchange in Sphagnum peatlands: Implications for the magnitude and direction of flux, J. Geophys. Res., 99, 14601-14607, https://doi.org/10.1029/94JD01025, 1994.

Elleuche, S. and Pöggeler, S.: Carbonic anhydrases in fungi, Microbiology, 156, 23-29, https://doi.org/10.1099/mic.0.032581-0, 2010.

Fabre, N., Reiter, I. M., Becuwe-Linka, N., Genty, B., and Rumeau, D.: Characterization and expression analysis of genes encoding $\alpha$ and $\beta$ carbonic anhydrases in Arabidopsis, Plant Cell Environ., 30, 617-629, https://doi.org/10.1111/j.1365-3040.2007.01651.x, 2007.

Fried, A., Klinger, L. F., and Erickson, D. J.: Atmospheric carbonyl sulfide exchange in bog microcosms, Geophys. Res. Lett., 20, 129-132, https://doi.org/10.1029/93GL00062, 1993.

Geng, C. and Mu, Y.: Carbonyl sulfide and dimethyl sulfide exchange between lawn and the atmosphere, J. Geophys. Res., 109, D12302, https://doi.org/10.1029/2003JD004492, 2004.

Gimeno, T. E., Ogée, J., Royles, J., Gibon, Y., West, J. B., Burlett, R., Jones, S. P., Sauze, J., Wohl, S., Benard, C., Genty, B., and Wingate, L.: Bryophyte gas-exchange dynamics along varying hydration status reveal a significant carbonyl sulphide (COS) sink in the dark and COS source in the light, New Phytol., 215, 965-976, https://doi.org/10.1111/nph.14584, 2017.

Haney, R. L. and Haney, E. B.: Simple and Rapid Laboratory Method for Rewetting Dry Soil for Incubations, Commun. Soil Sci. Plan., 41, 1493-1501, https://doi.org/10.1080/00103624.2010.482171, 2010.

Haritos, V. S. and Dojchinov, G.: Carbonic anhydrase metabolism is a key factor in the toxicity of $\mathrm{CO}_{2}$ and $\mathrm{COS}$ but not CS2 toward the flour beetle Tribolium castaneum [Coleoptera: Tenebrionidae], Comp. Biochem. Physiol., 140, 139-147, https://doi.org/10.1016/j.cca.2005.01.012, 2005.

Hines, M. E. and Morrison, M. C.: Emissions of biogenic sulfur gases from Alaskan tundra, J. Geophys. Res., 97, 16703-16707, https://doi.org/10.1029/90JD02576, 1992.

Jarvis, P. G., Rey, A., Petsikos, C., Wingate, L., Rayment, M. B., Pereira, J. S., Banza, J., David, J., Miglietta, F., Borgetti, M., and Valentini, R.: Drying and wetting of Mediterranean soils stimulates decomposition and carbon dioxide emission: the "Birch Effect”, Tree Physiol., 27, 929-940, 2007.

Katayama, Y., Narahara, Y., Inoue, Y., Amano, F., Kanagawa, T., and Kuraishi, H.: A thiocyanate hydrolase of Thiobacillus thioparus. A novel enzyme catalyzing the formation of carbonyl sulfide from thiocyanate, J. Biol. Chem., 267, 9170-9175, 1992.

Kato, H., Saito, M., Nagahata, Y., and Katayama, Y.: Degradation of ambient carbonyl sulfide by Mycobacterium spp. in soil, Microbiology, 154, 249-255, https://doi.org/10.1099/mic.0.2007/011213-0, 2008.

Kesselmeier, J., Teusch, N., and Kuhn, U.: Controlling variables for the uptake of atmospheric carbonyl sulfide by soil, J. Geophys. Res., 104, 11577-11584, https://doi.org/10.1029/1999JD900090, 1999.

Kettle, A. J., Kuhn, U., von Hobe, M., Kesselmeier, J., and Andreae, M. O.: Global budget of atmospheric carbonyl sulfide: Temporal and spatial variations of the dominant sources and sinks, J. Geophys. Res., 107, 4658, https://doi.org/10.1029/2002JD002187, 2002.
Kim, S.-J. and Katayama, Y.: Effect of growth conditions on thiocyanate degradation and emission of carbonyl sulfide by Thiobacillus thioparus THI115, Water Res., 34, 2887-2894, https://doi.org/10.1016/S0043-1354(00)00046-4, 2000.

Kitz, F., Gerdel, K., Hammerle, A., Laterza, T., Spielmann, F. M., and Wohlfahrt, G.: In situ soil COS exchange of a temperate mountain grassland under simulated drought, Oecologia, 183, 851-860, https://doi.org/10.1007/s00442-016-3805-0, 2017.

Kooijmans, L. M. J., Uitslag, N. A. M., Zahniser, M. S., Nelson, D. D., Montzka, S. A., and Chen, H.: Continuous and high-precision atmospheric concentration measurements of $\mathrm{COS}, \mathrm{CO}_{2}, \mathrm{CO}$ and $\mathrm{H}_{2} \mathrm{O}$ using a quantum cascade laser spectrometer (QCLS), Atmos. Meas. Tech., 9, 5293-5314, https://doi.org/10.5194/amt-95293-2016, 2016.

Launois, T., Belviso, S., Bopp, L., Fichot, C. G., and Peylin, P.: A new model for the global biogeochemical cycle of carbonyl sulfide - Part 1: Assessment of direct marine emissions with an oceanic general circulation and biogeochemistry model, Atmos. Chem. Phys., 15, 2295-2312, https://doi.org/10.5194/acp15-2295-2015, 2015.

Lehmann, S. and Conrad, R.: Characteristics of turnover of carbonyl sulfide in four different soils, J. Atmos. Chem., 23, 193-207, https://doi.org/10.1007/BF00048260, 1996.

Le Mer, J. and Roger, P.: Production, oxidation, emission and consumption of methane by soils: A review, Eur. J. Soil Biol., 37, 25-50, https://doi.org/10.1016/S1164-5563(01)01067-6, 2001.

Li, W., Yu, L., Yuan, D., Wu, Y., and Zeng, X.: A study of the activity and ecological significance of carbonic anhydrase from soil and its microbes from different karst ecosystems of Southwest China, Plant Soil, 272, 133-141, https://doi.org/10.1007/s11104004-4335-9, 2005.

Liu, J., Geng, C., Mu, Y., Zhang, Y., Xu, Z., and Wu, H.: Exchange of carbonyl sulfide (COS) between the atmosphere and various soils in China, Biogeosciences, 7, 753-762, https://doi.org/10.5194/bg-7-753-2010, 2010.

Maire, V., Alvarez, G., Colombet, J., Comby, A., Despinasse, R., Dubreucq, E., Joly, M., Lehours, A.-C., Perrier, V., Shahzad, T., and Fontaine, S.: An unknown oxidative metabolism substantially contributes to soil $\mathrm{CO}_{2}$ emissions, Biogeosciences, 10 , 1155-1167, https://doi.org/10.5194/bg-10-1155-2013, 2013.

Manina, G. and McKinney, J. D.: A Single-Cell Perspective on NonGrowing but Metabolically Active (NGMA) Bacteria, in: Pathogenesis of Mycobacterium tuberculosis and its Interaction with the Host Organism,Springer, Berlin, Heidelberg, 135-161, 2013.

Masaki, Y., Ozawa, R., Kageyama, K., and Katayama, Y.: Degradation and emission of carbonyl sulfide, an atmospheric trace gas, by fungi isolated from forest soil, FEMS Microbiol. Lett., 363, fnw197, https://doi.org/10.1093/femsle/fnw197, 2016.

Maseyk, K., Berry, J. A., Billesbach, D., Campbell, J. E., Torn, M. S., Zahniser, M., and Seibt, U.: Sources and sinks of carbonyl sulfide in an agricultural field in the Southern Great Plains, P. Natl. Acad. Sci. USA, 111, 9064-9069, https://doi.org/10.1073/pnas.1319132111, 2014.

Melillo, J. M. and Steudler, P. A.: The effect of nitrogen fertilization on the $\mathrm{COS}$ and $\mathrm{CS}_{2}$ emissions from temperature forest soils, J. Atmos. Chem., 9, 411-417, https://doi.org/10.1007/BF00114753, 1989. 
Melillo, J. M., McGuire, A. D., Kicklighter, D. W., Moore, B., Vorosmarty, C. J., and Schloss, A. L.: Global climate change and terrestrial net primary production, Nature, 363, p. 234, 1993.

Minami, K. and Fukushi, S.: Detection of carbonyl sulfide among gases produced by the decomposition of cystine in paddy soils, Soil Sci. Plant Nutr., 27, 105-109, https://doi.org/10.1080/00380768.1981.10431259, 1981a.

Minami, K. and Fukushi, S.: Volatilization of carbonyl sulfide from paddy soils treated with sulfurcontaining substances, Soil Sci. Plant Nutr., 27, 339-345, https://doi.org/10.1080/00380768.1981.10431288, 1981b.

Moldrup, P., Yoshikawa, S., Olesen, T., Komatsu, T., and Rolston, D. E.: Gas Diffusitivity in Undisturbed Volcanic Ash Soils, Soil Sci. Soc. Am. J., 67, 41-51, https://doi.org/10.2136/sssaj2003.3200, 2003.

Montzka, S. A., Calvert, P., Hall, B. D., Elkins, J. W., Conway, T. J., Tans, P. P., and Sweeney, C.: On the global distribution, seasonality, and budget of atmospheric carbonyl sulfide (COS) and some similarities to $\mathrm{CO}_{2}$, J. Geophys. Res., 112, D09302, https://doi.org/10.1029/2006JD007665, 2007.

Moroney, J. V., Bartlett, S. G., and Samuelsson, G.: Carbonic anhydrases in plants and algae, Plant Cell Environ., 24, 141-153, https://doi.org/10.1111/j.1365-3040.2001.00669.x, 2001.

Ogawa, T., Noguchi, K., Saito, M., Nagahata, Y., Kato, H., Ohtaki, A., Nakayama, H., Dohmae, N., Matsushita, Y., Odaka, M., Yohda, M., Nyunoya, H., and Katayama, Y.: Carbonyl Sulfide Hydrolase from Thiobacillus thioparus Strain THI115 Is One of the $\beta$-Carbonic Anhydrase Family Enzymes, J. Am. Chem. Soc., 135, 3818-3825, https://doi.org/10.1021/ja307735e, 2013.

Ogée, J., Sauze, J., Kesselmeier, J., Genty, B., Van Diest, H., Launois, T., and Wingate, L.: A new mechanistic framework to predict OCS fluxes from soils, Biogeosciences, 13, 2221-2240, https://doi.org/10.5194/bg-13-2221-2016, 2016.

Protoschill-Krebs, G. and Kesselmeier, J.: Enzymatic Pathways for the Consumption of Carbonyl Sulphide (COS) by Higher Plants, Bot. Acta, 105, 206-212, https://doi.org/10.1111/j.14388677.1992.tb00288.x, 1992.

Protoschill-Krebs, G., Wilhelm, C., and Kesselmeier, J.: Consumption of carbonyl sulphide (COS) by higher plant carbonic anhydrase (CA), Atmos. Environ., 30, 3151-3156, https://doi.org/10.1016/1352-2310(96)00026-X, 1996.

Raubuch, M., Dyckmans, J., Joergensen, R. G., and Kreutzfeldt, M.: Relation between respiration, ATP content, and Adenylate Energy Charge (AEC) after incubation at different temperatures and after drying and rewetting, J. Plant Nutr. Soil Sc., 165, 435-440, https://doi.org/10.1002/1522-2624(200208)165:4<435::AIDJPLN435>3.0.CO;2-3, 2002.

R Core Team: R: A Language and Environment for Statistical Computing, R Foundation for Statistical Computing, Vienna, Austria, available at: https://www.r-project.org/, last access: 7 March 2017.

Rhodes, C., Riddel, S. A., West, J., Williams, B. P., and Hutchings, G. J.: The low-temperature hydrolysis of carbonyl sulfide and carbon disulfide: a review, Catal. Today, 59, 443-464, https://doi.org/10.1016/S0920-5861(00)00309-6, 2000.

Roszak, D. B. and Colwell, R. R.: Survival strategies of bacteria in the natural environment, Microbiol. Rev., 51, 365-379, 1987.
Saito, M., Honna, T., Kanagawa, T., and Katayama, Y.: Microbial Degradation of Carbonyl Sulfide in Soils, Microbes Environ., 17, 32-38, https://doi.org/10.1264/jsme2.2002.32, 2002.

Sandoval-Soto, L., Stanimirov, M., von Hobe, M., Schmitt, V., Valdes, J., Wild, A., and Kesselmeier, J.: Global uptake of carbonyl sulfide (COS) by terrestrial vegetation: Estimates corrected by deposition velocities normalized to the uptake of carbon dioxide $\left(\mathrm{CO}_{2}\right)$, Biogeosciences, 2, 125-132, https://doi.org/10.5194/bg-2-125-2005, 2005.

Sauze, J., Ogée, J., Maron, P.-A., Crouzet, O., Nowak, V., Wohl, S., Kaisermann, A., Jones, S. P., and Wingate, L.: The interaction of soil phototrophs and fungi with $\mathrm{pH}$ and their impact on soil $\mathrm{CO}_{2}$, $\mathrm{CO}^{18} \mathrm{O}$ and OCS exchange, Soil Biol. Biochem., 115, 371-382, https://doi.org/10.1016/j.soilbio.2017.09.009, 2017.

Sauze, J., Jones, S. P., Wingate, L., Wohl, S., and Ogée, J.: The role of soil $\mathrm{pH}$ on soil carbonic anhydrase activity, Biogeosciences, 15, 597-612, https://doi.org/10.5194/bg-15-597-2018, 2018.

Sharma, V. K. and Graham, H. J. D.: Oxidation of amino acids, peptides and proteins by ozone: a review, Ozone: Science and Engineering, 32, 81-90, https://doi.org/10.1080/01919510903510507, 2010.

Smith, K. S. and Ferry, J. G.: Prokaryotic carbonic anhydrases, FEMS Microbiol. Rev., 24, 335-366, https://doi.org/10.1111/j.1574-6976.2000.tb00546.x, 2000.

Stimler, K., Berry, J. A., and Yakir, D.: Effects of Carbonyl Sulfide and Carbonic Anhydrase on Stomatal Conductance, Plant Physiol., 158, 524-530, https://doi.org/10.1104/pp.111.185926, 2012.

Sun, W., Maseyk, K., Lett, C., and Seibt, U.: A soil diffusionreaction model for surface COS flux: COSSM v1, Geosci. Model Dev., 8, 3055-3070, https://doi.org/10.5194/gmd-8-3055-2015, 2015.

Sun, W., Maseyk, K., Lett, C., and Seibt, U.: Litter dominates surface fluxes of carbonyl sulfide in a Californian oak woodland, J. Geophys. Res.-Biogeo., 121, 2015JG003149, https://doi.org/10.1002/2015JG003149, 2016.

Suntharalingam, P., Kettle, A. J., Montzka, S. M., and Jacob, D. J.: Global 3-D model analysis of the seasonal cycle of atmospheric carbonyl sulfide: Implications for terrestrial vegetation uptake, Geophys. Res. Lett., 35, L19801, https://doi.org/10.1029/2008GL034332, 2008.

Ueno, Y., Johnson, M. S., Danielache, S. O., Eskebjerg, C., Pandey, A., and Yoshida, N.: Geological sulfur isotopes indicate elevated OCS in the Archean atmosphere, solving faint young sun paradox, P. Natl. Acad. Sci. USA, 106, 14784-14789, https://doi.org/10.1073/pnas.0903518106, 2009.

Van Diest, H. and Kesselmeier, J.: Soil atmosphere exchange of carbonyl sulfide (COS) regulated by diffusivity depending on water-filled pore space, Biogeosciences, 5, 475-483, https://doi.org/10.5194/bg-5-475-2008, 2008.

Van Veldhoven, P. P. and Mannaerts, G. P.: Inorganic and organic phosphate measurements in the nanomolar range, Anal. Biochem., 161, 45-48, https://doi.org/10.1016/00032697(87)90649-X, 1987.

Wei, T. and Simko, V.: R package "corrplot": Visualization of a Correlation Matrix, available at: https://github.com/taiyun/corrplot, last access: 17 October 2017.

Whelan, M. E. and Rhew, R. C.: Carbonyl sulfide produced by abiotic thermal and photodegradation of soil organic mat- 
ter from wheat field substrate, J. Geophys. Res.-Biogeo., 120, 2014JG002661, https://doi.org/10.1002/2014JG002661, 2015.

Whelan, M. E. and Rhew, R. C.: Reduced sulfur trace gas exchange between a seasonally dry grassland and the atmosphere, Biogeochemistry, 128, 267-280, https://doi.org/10.1007/s10533016-0207-7, 2016.

Whelan, M. E., Min, D.-H., and Rhew, R. C.: Salt marsh vegetation as a carbonyl sulfide (COS) source to the atmosphere, Atmos. Environ., 73, 131-137, https://doi.org/10.1016/j.atmosenv.2013.02.048, 2013.

Whelan, M. E., Hilton, T. W., Berry, J. A., Berkelhammer, M., Desai, A. R., and Campbell, J. E.: Carbonyl sulfide exchange in soils for better estimates of ecosystem carbon uptake, Atmos. Chem. Phys., 16, 3711-3726, https://doi.org/10.5194/acp16-3711-2016, 2016.

Whelan, M. E., Lennartz, S. T., Gimeno, T. E., Wehr, R., Wohlfahrt, G., Wang, Y., Kooijmans, L. M. J., Hilton, T. W., Belviso, S., Peylin, P., Commane, R., Sun, W., Chen, H., Kuai, L., Mammarella, I., Maseyk, K., Berkelhammer, M., Li, K.-F., Yakir, D., Zumkehr, A., Katayama, Y., Ogée, J., Spielmann, F. M., Kitz, F., Rastogi, B., Kesselmeier, J., Marshall, J., Erkkilä, K.-M., Wingate, L., Meredith, L. K., He, W., Bunk, R., Launois, T., Vesala, T., Schmidt, J. A., Fichot, C. G., Seibt, U., Saleska, S., Saltzman, E. S., Montzka, S. A., Berry, J. A., and Campbell, J. E.: Reviews and Syntheses: Carbonyl Sulfide as a Multi-scale Tracer for Carbon and Water Cycles, Biogeosciences Discuss., https://doi.org/10.5194/bg-2017-427, in review, 2017.
Wilhelm, E., Battino, R., and Wilcock, R. J.: Low-pressure solubility of gases in liquid water, Chem. Rev., 77, 219-262, https://doi.org/10.1021/cr60306a003, 1977.

Wingate, L., Ogée, J., Cuntz, M., Genty, B., Reiter, I., Seibt, U., Yakir, D., Maseyk, K., Pendall, E., Barbour, M. M., Mortazavi, B., Peylin, P., Miller, J., Mencuccini, M., Burlett, R., Shim, J. H., Hunt, J., and Grace, J.: The influence of soil micro-organisms on the oxygen isotope signal of atmospheric $\mathrm{CO}_{2}$, P. Natl. Acad. Sci. USA, 106, 22411-22415, https://doi.org/10.1073/pnas.0905210106, 2009

Yi, Z. and Wang, X.: Carbonyl sulfide and dimethyl sulfide fluxes in an urban lawn and adjacent bare soil in Guangzhou, China, J. Environ. Sci., 23, 784-789, https://doi.org/10.1016/S10010742(10)60478-0, 2011.

Yi, Z., Wang, X., Sheng, G., Zhang, D., Zhou, G., and Fu, J.: Soil uptake of carbonyl sulfide in subtropical forests with different successional stages in south China, J. Geophys. Res., 112, D08302, https://doi.org/10.1029/2006JD008048, 2007.

Zoppini, A. and Marxsen, J.: Importance of Extracellular Enzymes for Biogeochemical Processes in Temporary River Sediments during Fluctuating Dry-Wet Conditions, in: Soil Enzymology, Springer, Berlin, Heidelberg, 103-117, 2010. 